\title{
Integrated Magneto-Electrochemical Sensor for Exosome Analysis
}

\section{Citation}

Jeong, Sangmoo, Jongmin Park, Divya Pathania, Cesar M. Castro, Ralph Weissleder, and Hakho Lee. 2016. "Integrated Magneto-Electrochemical Sensor for Exosome Analysis." ACS Nano 10 (2): 1802-9. https://doi.org/10.1021/acsnano.5b07584.

\section{Permanent link}

http://nrs.harvard.edu/urn-3:HUL.InstRepos:41384383

\section{Terms of Use}

This article was downloaded from Harvard University's DASH repository, and is made available under the terms and conditions applicable to Open Access Policy Articles, as set forth at http:// nrs.harvard.edu/urn-3:HUL.InstRepos:dash.current.terms-of-use\#OAP

\section{Share Your Story}

The Harvard community has made this article openly available.

Please share how this access benefits you. Submit a story.

Accessibility 


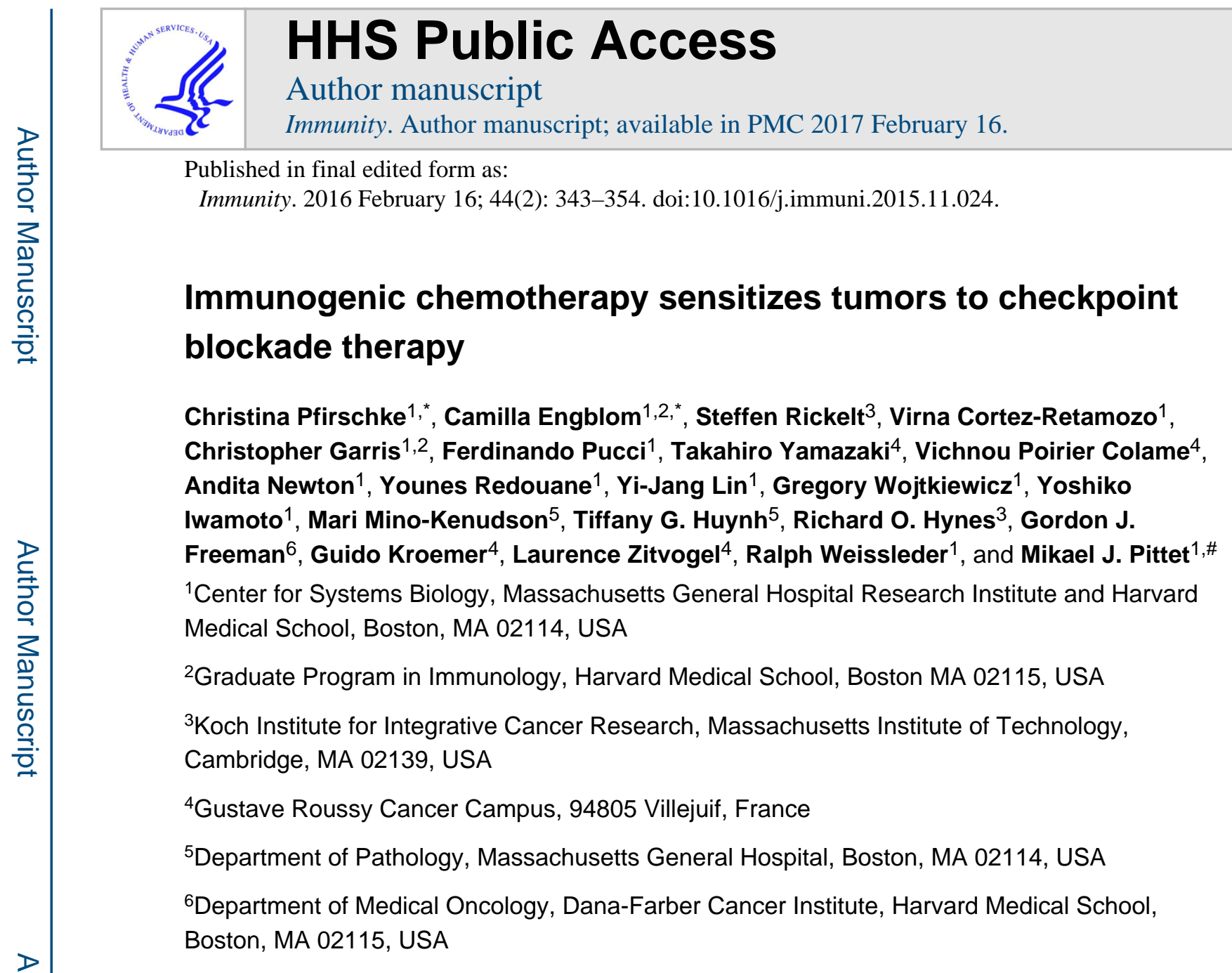

\section{SUMMARY}

Checkpoint blockade immunotherapies can be extraordinarily effective, but may benefit only the minority of patients whose tumors are pre-infiltrated by $\mathrm{T}$ cells. Here, using lung adenocarcinoma mouse models, including genetic models, we show that autochthonous tumors that lacked $\mathrm{T}$ cell infiltration and resisted current treatment options could be successfully sensitized to host antitumor $\mathrm{T}$ cell immunity when using appropriately selected immunogenic drugs (e.g. oxaliplatin combined with cyclophosphamide for treatment against tumors expressing oncogenic Kras and lacking Trp53). The antitumor response was triggered by direct drug actions on tumor cells, relied on innate immune sensing through toll-like receptor 4 signaling, and ultimately depended on

\footnotetext{
${ }^{\#}$ Correspondence: mpittet@mgh.harvard.edu (M.J.P).

* These authors contributed equally to this work

Publisher's Disclaimer: This is a PDF file of an unedited manuscript that has been accepted for publication. As a service to our customers we are providing this early version of the manuscript. The manuscript will undergo copyediting, typesetting, and review of the resulting proof before it is published in its final citable form. Please note that during the production process errors may be discovered which could affect the content, and all legal disclaimers that apply to the journal pertain.

SUPPLEMENTAL INFORMATION

Supplemental information includes five figures and Supplemental Experimental Procedures.

AUTHOR CONTRIBUTIONS

C.P. and C.E. designed the study, performed experiments, analyzed data and wrote the manuscript. S.R., M.M-K. and T.H. performed immunohistochemistry and analysis. V.C.R., C.G., F.P., T.Y., V.P.C., A.N., Y.R., Y-J.L. performed experiments, generated and analyzed data. G.W. performed and analyzed murine $\mu \mathrm{CT}$ and MRI data. Y.I. conducted tissue sectioning and slide scanning. R.O.H., G.J.F., G.K., L.Z. and R.W. provided input for research design and interpretation and edited the manuscript. M.J.P. directed the study and wrote the manuscript.
} 
$\mathrm{CD} 8^{+} \mathrm{T}$ cell antitumor immunity. Furthermore, instigating tumor infiltration by $\mathrm{T}$ cells sensitized tumors to checkpoint inhibition and controlled cancer durably. These findings indicate that the proportion of cancers responding to checkpoint therapy can be feasibly and substantially expanded by combining checkpoint blockade with immunogenic drugs.

\section{INTRODUCTION}

The ability of the immune system to control tumor cells was proposed more than a century ago, demonstrated during the last decade, and recently harnessed for therapy (Sharma and Allison, 2015; Topalian et al., 2015). A foundational principle of tumor immunology is that cancer cells can be eliminated by host cytotoxic CD8 ${ }^{+} \mathrm{T}$ cells (Schreiber et al., 2011; Gajewski et al., 2013; Schumacher and Schreiber, 2015; Rooney et al., 2015). Accordingly, $\mathrm{CD} 8^{+} \mathrm{T}$ cell infiltration of various solid tumor types has positive prognostic value (Fridman et al., 2012), although these cells can be subject to various suppressive mechanisms including inhibition by regulatory $\mathrm{T}$ (Treg) cells and induced expression of programmed death-1 (PD-1) and other inhibitory checkpoint receptors, all limiting the antitumor functions of lymphocytes (Sharma and Allison, 2015; Topalian et al., 2015).

Therapies targeting $\mathrm{T}$ cell inhibitory checkpoint signaling pathways are redefining cancer therapy because clinical trials show unprecedented rates of durable responses in patients with common cancer types, including lung adenocarcinoma (Topalian et al., 2015). Lung adenocarcinoma was long considered to be nonimmunogenic and is the leading cause of cancer incidence and mortality worldwide, with more than one million deaths per year (Torre et al., 2015). Yet, only a minority of cancer patients respond to checkpoint inhibition and evidence suggests that those patients may preferentially have tumors that have favorable mutational landscapes, express the PD-1 ligand (PD-L1) and/or contain pre-existing tumorinfiltrating $\mathrm{CD}^{+} \mathrm{T}$ cells that are inhibited locally, e.g., by PD-1 engagement (Tumeh et al., 2014; Sharma and Allison, 2015; Rizvi et al., 2015; Schumacher and Schreiber, 2015; Herbst et al., 2014; Topalian et al., 2012; Topalian et al., 2015). In order to define the proportion of patients who could ultimately benefit from immunotherapies, it appears important to clarify whether strategies can be employed for converting tumor microenvironments lacking $\mathrm{T}$ cell infiltration to ones displaying antitumor $\mathrm{T}$ cell immunity and then to determine whether this process sensitizes tumors to checkpoint therapy.

One approach to achieving this goal may involve the induction of immunogenic conditions in the tumor microenvironment. For example, some chemotherapeutics and other treatments shape clinical outcome by influencing tumor-host interactions to stimulate $\mathrm{T}$ cell immunosurveillance (Zitvogel et al., 2013; Klug et al., 2013; Shalapour et al., 2015). The drugs prescribed today against lung adenocarcinomas only marginally increase survival. Despite their low success rate, these drugs deserve re-consideration for several reasons, especially when combined with immunotherapy: $i$ ) they were originally selected for their capacity to prevent human tumor cell growth in vitro and in xenotransplanted immunodeficient mouse models without considering the relevance of immune reactions to treatment outcomes; ii) they are generally given indiscriminately even though their impact 
may vary across individuals and tumor microenvironments and iii) improved understanding of drug effects in vivo may help identify synergistic treatment options.

To address these knowledge gaps we explored conditional genetic lung adenocarcinoma models (with Kras and Trp53 mutations, referred to as KP), in addition to orthotopic KP lung tumor models. In the genetic models, cancer cells are derived from somatic cells that are transformed in their normal tissue microenvironment and progress to high-grade tumors that lack $\mathrm{T}$ cell infiltration and resist prescribed chemo- and immunotherapeutic treatments. These models can also be used to study autochthonous tumors that express model neoantigens, which are important drivers of antitumor T cell immunity (Gubin et al., 2014; Rooney et al., 2015) and targets of checkpoint blockade therapy (Schumacher and Schreiber, 2015). The genetic tumor models we used for this study also avoid the inherent limitations of tumor grafts, including sensitivity to numerous chemotherapeutic agents (Olive et al., 2009).

Here we identified that a combination of clinically-approved chemotherapeutic drugs (oxaliplatin-cyclophosphamide; Oxa-Cyc) elicited immunogenic phenotypes on KP tumor cells. We also found that Oxa-Cyc treatment fostered $\mathrm{CD}^{+} \mathrm{T}$ cell infiltration into KP tumors and delayed cancer progression. Tumor control depended on direct drug actions on tumor cells and required both $\mathrm{CD}^{+} \mathrm{T}$ cells and TLR $4^{+}$cells. Importantly, the immunogenic chemotherapeutics successfully sensitized KP lung adenocarcinomas to immune checkpoint blockade. We extended these findings to other tumor types. Consequently, this study suggests that anticancer drugs that are rationally selected for triggering tumor immunogenicity can be used to make resistant tumors sensitive to checkpoint blockade therapy.

\section{RESULTS}

\section{KP lung adenocarcinomas resist current treatment options}

Kirsten rat sarcoma viral oncogene homolog (KRAS) and tumor suppressor p53 (TP53) genes are mutated in $\sim 25 \%$ and $50 \%$, respectively, in non-small cell lung cancer (NSCLC) patients. Initially, we examined $\mathrm{Kras}{ }^{L S L-G 12 D /+}$; Trp $53_{\text {floxfflox }}$ (hereafter KP) mice that express endogenous mutant Kras and deleted Trp53 alleles in lung epithelial cells upon administration of adenovirus expressing Cre recombinase (Cortez-Retamozo et al., 2013). These mice develop lung adenocarcinomas with both pathophysiological and molecular features of the human disease. Evaluation of the lungs of KP tumor-bearing mice revealed the presence of $\mathrm{CD}^{+} \mathrm{T}$ cells only within the normal tissue parenchyma and at frequencies comparable to those in tumor-free mice; by contrast, all the KP lung adenoma and adenocarcinoma nodules lacked $\mathrm{CD}^{+} \mathrm{T}$ cell infiltration (Figures $1 \mathrm{~A}$ and $\mathrm{S} 1 \mathrm{~A}-\mathrm{C}$ ). As anticipated for tumors lacking pre-infiltrated T cells, anti-PD-1 monoclonal antibody (mAb) treatment failed to delay KP tumor progression (data not shown) and did not increase KP mouse survival as defined by the Kaplan-Meier estimator (Figure 1B). Similar results were obtained for KP mice on the 129 and C57BL/6 backgrounds (data not shown).

We extended our examination to wild-type mice bearing orthotopic syngeneic KP1.9 lung adenocarcinomas harboring Kras and Trp53 mutations. Anti-PD-1 treatment also failed to 
control tumor progression in this model (Figure 1C). Using a third mouse model, we examined whether introducing neoantigens sensitizes KP tumors to immune checkpoint therapy. We gave KP mice a Cre-based lentiviral vector containing ovalbumin (OVA) peptide sequences to produce KP-OVA mice bearing tumors expressing model OVA neoantigens (DuPage et al., 2011). These mice were treated with both anti-PD-1 and anticytotoxic T-lymphocyte-associated protein 4 (CTLA-4) mAbs because combined checkpoint blockade can increase response rates in cancer patients (Sharma and Allison, 2015; Postow et al., 2015; Wolchok et al., 2013). Treatment was initiated on day 133 when lung adenocarcinomas were detectable by micro-computed tomography (Figure 1D) and poorly infiltrated by $\mathrm{CD}^{+}{ }^{+} \mathrm{T}$ cells (DuPage et al., 2011). KP-OVA tumors remained refractory to anti-PD-1 and anti- CTLA-4 mAb combination therapy (Figure 1D).

We also assessed the effects of mainstay lung cancer chemotherapeutics in KP mice. Besides cisplatin treatment, which only marginally controls KP tumor progression (Oliver et al., 2010), we evaluated paclitaxel (Ptax) and carboplatin (Carbo), which are often administered in combination because of their synergistic effects on microtubule and DNA damage, respectively. We observed that Ptax-Carbo treatment failed both to curb KP tumor progression (Figures 1E and S1D) and to extend KP mouse survival (Figure 1F). We also assessed tumor infiltration by $\mathrm{CD} 8^{+} \mathrm{T}$ cells in 76 tumor biopsy sections from NSCLC patients who were genotyped for KRAS, TP53 and epidermal growth factor receptor (EGFR) mutations. We did not detect differences in $\mathrm{CD}^{+} \mathrm{T}$ cell infiltration based on the KRAS or EGFR status of tumors; however, TP53-mutated tumors as well as TP53-KRAS-double mutated tumors showed significantly reduced $\mathrm{CD} 8^{+} \mathrm{T}$ cell infiltration compared to their nonmutated counterparts (Figures S1E and S1F). Taken together, these results indicate that the KP mouse model is relevant to explore tumors that share important features with their human counterparts and, most importantly, resist current immuno- and chemotherapeutic interventions.

\section{Selected chemotherapeutics induce KP tumor cell immune phenotypes}

Considering that KP tumor nodules lack T cells, we hypothesized that therapeutically reversing this phenotype might help control cancer progression. To this end, we initially tested diverse chemotherapeutic drug combinations for their ability to induce immunogenic phenotypes in various KP tumor cell lines (KP L1-3, L1-5 and L2-9) in vitro. These proof of principle studies used high mobility group box 1 (HMGB1) release as a surrogate marker for drug-induced tumor cell immunogenicity (Zitvogel et al., 2013) and evaluated Food and Drug Administration (FDA)-approved chemotherapeutics to favor clinical translatability. We found that the NSCLC chemotherapeutics docetaxel (Dtax) and Carbo, alone or in combination, failed to induce HMGB1 release by all KP tumor cell lines tested (Figure 2A). Likewise, the anthracycline mitoxantrone (Mtx), which can have immunogenic effects (Kroemer et al., 2013), did not trigger HMGB1 release by KP tumor cells, even when combined with mafosfamide (Maf) (Figure 2B), which is the active metabolite of cyclophosphamide (Cyc) (Schiavoni et al., 2011). However, the oxaliplatin-mafosfamide (Oxa-Maf) combination stimulated HMGB1 release by all KP tumor cell lines (Figures 2A and 2B). This combination also triggered calreticulin (CRT) exposure by living KP tumor cells (Figure 2C), which is an additional marker of cell immunogenicity (Zitvogel et al., 
2013). Building on these observations, we tested the combined Oxa-Cyc treatment in tumorbearing KP mice using well tolerated drug concentrations (Figures S2A and S2B). Unlike Ptax-Carbo, Oxa- Cyc treatment significantly increased nuclear HMGB1 staining within KP tumor nodules (Figures 2D and S2C), a result that mirrors our in vitro findings. These data demonstrate that selected chemotherapeutics can induce immunogenic phenotypes in KP lung adenocarcinoma cells both in vitro and in vivo.

\section{Chemotherapeutics selected for their ability to induce immunogenicity in tumors delay KP cancer progression}

KP mice sacrificed after 3 weeks of Oxa-Cyc treatment showed significantly lower tumor burden compared to Ptax-Carbo-treated or untreated mice (Figures 3A and S3A-C). We confirmed the ability of Oxa-Cyc treatment to control cancer growth in mice bearing KP1.9 tumors (Figures S3D-F). As the above experiments used terminal procedures to assess tumors at different time points and in different mice, we also used in vivo micro-computed tomography to monitor lung tumor volumes over time noninvasively to gain quantitative information on lung tumor progression in individual KP mice. This approach confirmed overall control of KP tumor growth during Oxa-Cyc treatment duration (Figure 3B). By contrast, Ptax-Carbo treatment only showed a limited ability to suppress cancer progression. In Oxa-Cyc-treated mice we found that some tumor nodules progressed whereas others regressed (Figure 3B) and that tumor cell apoptosis, defined by cleaved caspase 3 staining, increased in some but not all tumor nodules (Figure S3G). These data demonstrate the possibility of significantly altering KP tumor growth with rationally selected and clinically approved chemotherapeutics.

\section{Drug-induced tumor control involves a systemic host response}

Having identified Oxa-Cyc as a model of successful treatment against KP tumors, we explored how it controlled cancer progression at a mechanistic level in vivo. First, we asked whether restricting Oxa-Cyc exposure to KP tumor cells is sufficient to alter cancer progression. To address this question, C57BL/6 mice received multiple injections of KP1.9 cells previously killed in vitro with either Oxa-Maf or Ptax-Carbo (days $-8,-4,-2,5,12$ ); the mice were also challenged with viable KP1.9 cells on day 0 . We found that the tumors grew more slowly in mice vaccinated with cells killed with Oxa-Maf compared to mice vaccinated with tumor cells killed with Ptax-Carbo (Figure 4A). This difference highlighted that tumor control is not just a consequence of immunization with dead cells. Of interest, the vaccinations had identical effects on tumors injected either ipsior contralaterally, thereby further indicating systemic rather than local vaccination-induced effects. Importantly, prophylactic vaccination (i.e. Oxa-Maf-killed tumor cells injected on days $-8,-4,-2$ only) was sufficient to reduce both ipsi- and contralateral tumor growth (Figure 4B). Consequently, these results indicate that Oxa- Maf-sensitized tumor cells induced systemic changes that subsequently reduced cancer progression.

\section{Drug-induced tumor control involves adaptive immunity}

Our next step evaluated whether Oxa-Cyc sensitization in vivo promoted an antitumor immune response. By collecting single cell suspensions from KP mouse lungs we found 
increased $\mathrm{CD}^{+} \mathrm{T}$ cell:Treg cell ratios in Oxa-Cyc-treated mice as compared to untreated or Ptax-Carbo-treated mice (Figure $4 \mathrm{C}$ ). The increased $\mathrm{CD} 8^{+} \mathrm{T}$ cell:Treg cell ratio favors $\mathrm{CD}^{+} \mathrm{T}$ cell-mediated cancer immune surveillance and is associated with beneficial outcome (Sato et al., 2005; Gao et al., 2007). In further assessing the distribution of T cells in KP mouse lungs by immunohistochemistry, we found that Oxa-Cyc treatment instigated $\mathrm{CD}^{+}$within tumor nodules (Figures $4 \mathrm{D}$ and $\mathrm{S} 4 \mathrm{~A}$ ), with some $\mathrm{CD}^{+}$cells proliferating locally as revealed by Ki67 staining (Figure S4B). The tumor-infiltrating $\mathrm{CD}^{+} \mathrm{T}$ cells, which were absent in untreated or Ptax-Carbo-treated mice, were mostly $\mathrm{CD} 8^{+}$and rarely $\mathrm{CD}^{+}$(Figures 4E and S4C), thereby indicating Oxa-Cyc's ability to instigate CD8 ${ }^{+} \mathrm{T}$ cell infiltration into, and proliferation within, KP tumors.

Since Cyc can suppress Tregs (Ghiringhelli et al., 2004; Lutsiak et al., 2005), Oxa-Cyc might promote antitumor responses by acting on Tregs directly. However, our data suggested that the $\mathrm{CD} 8^{+} \mathrm{T}$ cell response induced by Oxa-Cyc against KP tumors preferentially follows the induction of drug-mediated tumor cell immunogenicity because Oxa-Cyc treatment increased $\mathrm{CD} 8^{+} \mathrm{T}$ cell:Treg cell ratios selectively in lung tumor tissue (i.e. not systemically, Figure 4F) and Tregs (as fractions of $\mathrm{CD}^{+}$cells) were already absent from tumor nodules of untreated mice (Figure S4A). Also, lung $\mathrm{CD}^{+} \mathrm{T}$ cell:Treg cell ratios increased more in mice that received both Oxa and Cyc (Figure 4F), a result that was in accordance with our in vitro observations that inducing tumor cell immunogenic phenotypes required the drug combination (Figures 2A-C).

To test whether therapeutically controlling KP tumor progression needs adaptive immunity, we generated $\mathrm{Rag}^{-/-} \mathrm{KP}$ mice in the C57BL/6 background (Figures S4D-F). The inability of Oxa-Cyc to suppress tumor progression in these mice (Figures $4 \mathrm{G}$ and $\mathrm{S} 4 \mathrm{G}$ ) favors the hypothesis that KP tumor control requires $\mathrm{CD} 8^{+} \mathrm{T}$ cells. Because $\mathrm{Rag}^{-/-} \mathrm{KP}$ mice lack both $\mathrm{T}$ and B cells (Figures S4E and S4F), we also investigated the influence of selective $\mathrm{CD}^{+} \mathrm{T}$ cell ablation in immunocompetent $\left(\mathrm{Rag}^{+/+}\right) \mathrm{KP}$ mice using $\mathrm{CD} 8$ depleting mAbs (Figure $\mathrm{S} 4 \mathrm{H}$ ). Oxa-Cyc failed to suppress tumor progression in $\mathrm{CD}^{+} \mathrm{T}$ cell-depleted mice (Figure 4H), which indicated that Oxa-Cyc not only instigated tumor infiltration by $\mathrm{CD}^{+} \mathrm{T}$ cells but also needed these cells to control cancer growth. Tumor control in KP mice was very efficient, especially considering that this mouse model resists all conventional treatments and develops tumors that are generally viewed as non-immunogenic.

\section{Drug-induced tumor control involves innate immunity}

To delve deeper into drug action mechanisms we next examined whether Oxa-Cyc-induced antitumor immunity required variables other than tumor-cell targeting and $\mathrm{CD} 8^{+} \mathrm{T}$ cells. $\mathrm{We}$ investigated innate immune cells because they are found in the KP tumor stroma (CortezRetamozo et al., 2012) and may be modulated by drugs to induce tumor control (Broz and Krummel, 2015; De Palma and Lewis, 2013). To uncover possible drug-induced changes on innate immune cell subsets, we collected lung tissue biopsies of KP tumor-bearing mice treated or not with Oxa-Cyc for comparative ex vivo analysis by multi-parameter flow cytometry. Furthermore, we isolated both tumor stroma biopsies and tumor-free adjacent lung tissue to assess whether drug-induced changes selectively control the immediate tumor microenvironment. By operationally dividing $\mathrm{CD}_{4} 5^{+} \mathrm{Lin}^{-}$myeloid cells into $\mathrm{CD} 11 \mathrm{~b}^{-}$and 
$\mathrm{CD} 11 \mathrm{~b}^{+}$cell subsets, we observed a substantial decrease in the frequency of CD11 $\mathrm{b}^{-}$cells in both the tumor stroma and adjacent tissue following Oxa-Cyc therapy (Figure 5A). This decrease was also observed in Ptax-Carbo-treated mice (data not shown), suggesting that this cell loss is insufficient to explain tumor control selectively in Oxa-Cyc-treated mice. In marked contrast, Oxa-Cyc treatment significantly and selectively increased the frequency of the $\mathrm{CD} 11 \mathrm{~b}^{+}$cell subset within the tumor stroma (Figure 5A). These findings indicate OxaCyc treatment modulates innate immune system components within the tumor microenvironment.

We further analyzed CD11 $\mathrm{b}^{+}$cells, and subsets thereof, and considered toll-like receptor 4 (TLR4) because it can be involved in innate immune activation and transition toward adaptive immunity in the context of druginduced immunogenic cell death (Apetoh et al., 2007; Kroemer et al., 2013). We found that Oxa-Cyc treatment upregulated TLR4 selectively in the dendritic cell (DC)/macrophage-like subset, defined as CD11 $\mathrm{b}^{+} \mathrm{CD} 11 \mathrm{c}^{+}$ Ly- $6 \mathrm{G}^{-}$Ly-6C-- TLR4 upregulation occurred only within the tumor stroma but not in tumor-free adjacent tissue (Figure 5B). By comparison, the mean fluorescent intensity (MFI) of cell surface TLR4 expression was low or undetectable in $\mathrm{CD} 11 \mathrm{~b}^{+} \mathrm{CD} 11 \mathrm{c}^{-}$cells, $\mathrm{Ly}^{-} 6 \mathrm{G}^{+} /$ Ly- $6 \mathrm{C}^{+}$granulocytes and Ly- $6 \mathrm{C}^{+}$monocyte-like cells, both in absence or presence of OxaCyc treatment (Figure 5B). We also found that $\mathrm{CD} 11 \mathrm{~b}^{+} \mathrm{CD} 11 \mathrm{c}^{+}$cells, in contrast to their

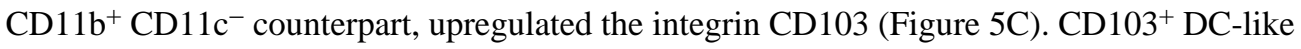
cells are important in regulating antitumor immunity because they have enhanced abilities to activate $\mathrm{CD} 8^{+} \mathrm{T}$ cells compared to $\mathrm{CD} 103^{-}$DCs and tumor-associated macrophages (Broz et al., 2014; Ruffell et al., 2014; Spranger et al., 2015).

To define whether TLR4 ${ }^{+}$cells are required for generating drug-induced KP tumor control, we examined the impact of Oxa-Cyc treatment on tumor-associated $\mathrm{T}$ cell responses in $T l r 4^{-/-}$mice. In contrast to their wild-type counterparts, $T l r 4^{-/}$mice failed to increase lung $\mathrm{CD} 8^{+} \mathrm{T}$ cell:Treg cell ratios following Oxa-Cyc treatment (Figure 5D). Furthermore, we found that TLR4 deficiency reduced Oxa-Cyc-mediated control of KP tumor progression (Figure 5E). These data provide evidence that triggering successful antitumor $\mathrm{T}$ cell immunity against KP tumors with Oxa-Cyc depends on TLR4, in line with previous findings that this receptor can promote DC-mediated $\mathrm{CD} 8^{+} \mathrm{T}$ cell activation (Apetoh et al., 2007).

\section{Immunogenic chemotherapeutics sensitize lung adenocarcinomas to immune checkpoint therapy}

With the ability to convert non-T cell infiltrated KP tumors into ones that display antitumor $\mathrm{T}$ cell immunity, we asked whether this process can be harnessed for sensitizing KP tumors to checkpoint blockade therapy. We used the KP-OVA mouse model because it is refractory to the anti-PD-1 and anti-CTLA-4 mAb combination therapy (Figure 1D) and allowed us to track CD8 ${ }^{+} \mathrm{T}$ cells specific for the model antigen $\mathrm{OVA}_{257-264}$. We found that Oxa-Cyc treatment in these mice favored or maintained four phenotypes that are potentially associated with response to PD-1 checkpoint inhibition, namely: $i$ ) increased $\mathrm{CD} 8^{+} \mathrm{T}$ cell:Treg cell ratio in the lung tumor tissue (Figure 6A); ii) presence of tumor-infiltrating OVA-specific CD8 ${ }^{+} \mathrm{T}$ cells (Figure 6B); iii) PD-1 expression by these cells (Figure 6C) and iv) PD-L1 expression by tumor-associated host and/or tumor cells (Figure 6D). 
We conducted a blinded preclinical study in which KP-OVA mice received Oxa-Cyc, antiPD-1 + anti-CTLA-4 mAbs or both, with controls left untreated (Figure S5A). Treatments began on day 130 after tumor initiation and tumors were monitored noninvasively by high resolution micro-computed tomography in all mice at three time points (day 122, day 146, and day 193) to quantify changes in tumor burden in vivo. All mice were evaluated ex vivo at day 234 .

Noninvasive tumor assessment at days 122, 146 and $193\left(\mathrm{~T}_{0}, \mathrm{~T}_{1}\right.$ and $\left.\mathrm{T}_{2}\right)$ revealed that OxaCyc controlled KP tumors during the first 3 weeks of treatment $\left(T_{0 \rightarrow} T_{1}\right)$ when compared to untreated mice $(\mathrm{p}<0.05)$ but was unable to control tumors at later time points $\left(\mathrm{T}_{0 \rightarrow} \mathrm{T}_{2}, \mathrm{p}>\right.$ 0.05) (Figure 6E). Checkpoint inhibition failed to delay KP tumor progression $\left(\mathrm{T}_{0 \rightarrow} \mathrm{T}_{1}, \mathrm{p}>\right.$ $\left.0.05 ; \mathrm{T}_{0 \rightarrow} \mathrm{T}_{2}, \mathrm{p}>0.05\right)$. By contrast, Oxa-Cyc combined with anti-PD-1 + anti- CTLA-4 $\mathrm{mAb}$ treatment controlled tumor progression at both time points $\left(\mathrm{T}_{0 \rightarrow} \mathrm{T}_{1}, \mathrm{p}<0.01 ; \mathrm{T}_{0 \rightarrow} \mathrm{T}_{2}, \mathrm{p}\right.$ $<0.05$ ) (Figures 6E and 6F).

Post mortem evaluation at day $234\left(\mathrm{~T}_{3}\right)$ validated the advantage of the combination treatment to suppress KP tumors durably (i.e. over 16 weeks; $p<0.001$; Figures $6 \mathrm{E}$ and $6 \mathrm{G}$ ). The combination treatment was significantly better than either Oxa-Cyc or anti-PD- $1+$ antiCTLA-4 alone (Figures 6E and 6G).

Multiphoton microscopy of explanted lung tissue confirmed successful tumor control in the same mice. This approach further revealed the $\mathrm{CD} 8^{+} \mathrm{T}$ cells' selective ability to accumulate and remain within tumor nodules of Oxa-Cyc-treated KP-OVA mice, whether or not they received the immune checkpoint blockers (Figures 6H, S5B and S5C). These data support the idea that tumor infiltration by $\mathrm{CD} 8^{+} \mathrm{T}$ cells is insufficient to durably control cancer progression but can generate effective responses to checkpoint blockade treatment.

Additionally, when using the KP1.9 tumor-bearing mouse model, we found that Oxa-Cyc treatment significantly increased overall mouse survival when combined with anti-PD-1 + anti-CTLA-4 mAbs, whereas anti-PD-1 or anti-CTLA-4 alone did not confer protection (Figure S5D). Comparisons of various combination treatments suggested that anti-PD-1 $\mathrm{mAb}$ treatment was mostly responsible for improving Oxa-Cyc treatment efficacy in the KP1.9 tumor-bearing mice at least 20 days after initiation of treatment (Figure S5E). Taken together these data indicate that rationally selected immunogenic chemotherapeutics can sensitize KP lung adenocarcinomas to immune checkpoint therapy.

\section{Immunogenic chemotherapeutics can sensitize other tumors to immune checkpoint therapy}

Finally, we tested whether other immunogenic chemotherapeutics could sensitize tumors to immune checkpoint therapy. We explored MCA205 fibrosarcoma-bearing mice because they failed to respond to anti- PD-1 + anti-CTLA-4 mAbs (Figure 7A). We found that cisplatin treatment, which does not induce immunogenic cell death, failed to improve immune checkpoint blockade treatment (Figure 7A). By contrast, doxorubicin, which induces MCA205 immunogenic cell death (Zitvogel et al., 2013), significantly delayed tumor progression when combined with anti-PD-1 + anti-CTLA-4 mAb therapy (Figure $7 \mathrm{~A})$. 
We also investigated CT26 colon carcinoma-bearing mice, which did not respond to antiCTLA-4 mAb therapy (Figure 7B). Oxa treatment induces immunogenic CT26 tumor cell death (Apetoh et al., 2007; Tesniere et al., 2010) and increases CD8 ${ }^{+} \mathrm{T}$ cell infiltration at the tumor site (Gou et al., 2014). We found that Oxa treatment provided minimal control of CT26 tumor progression, similarly to cisplatin, which was used as a control agent (Figure 7B). Checkpoint blockade therapy with anti-CTLA-4 mAb, either as monotherapy or combined with cisplatin, was also largely ineffective. However, the Oxa + anti-CTLA-4 combination was able to reject CT26 tumors in $\sim 40 \%$ of mice analyzed (Figure 7B). These results demonstrate that our findings in the KP mouse model can be extended to other tumor types; they also indicate that tailoring chemotherapy treatments to a given tumor type may be a generalizable approach to sensitize tumors to immune checkpoint therapy.

\section{DISCUSSION}

We used genetically-engineered mouse models that closely recapitulate human disease to examine whether autochthonous tumors lacking pre-infiltrated $\mathrm{T}$ cells can also be sensitized therapeutically to induce $\mathrm{T}$ cell-mediated control of tumor progression. We investigated lung adenocarcinomas carrying common KRAS and/or TP53 mutations because we identified these tumors to be inadequately infiltrated by $\mathrm{CD} 8^{+} \mathrm{T}$ cells in both humans and mice. In addition, we found that Kras/Trp53 mutant tumors in mice resist current chemo- and immunotherapies even when tumors expressed neoantigens, which are targets of successful checkpoint blockade therapy. We report that appropriately selected and clinically approved therapeutics can produce $\mathrm{CD} 8^{+} \mathrm{T}$ cell infiltration in otherwise non- $\mathrm{T}$ cell inflamed tumors and that this process inhibits cancer progression. Furthermore, the $\mathrm{T}$ cell response induced by immunogenic chemotherapeutics can be harnessed to sensitize lung adenocarcinomas to immune checkpoint therapy. The antitumor response triggered by the immunogenic chemotherapeutics depended on: 1) direct drug actions on tumor cells; 2) host $\mathrm{CD} 8^{+} \mathrm{T}$ cell activation; and 3) intact TLR4 signaling.

First, Oxa-Cyc-induced effects on tumor cells alone can trigger a systemic antitumor response. Indeed, injecting tumor-bearing mice with KP1.9 tumor cells previously killed by Oxa-Maf (but not by Ptax-Carbo) efficiently inhibited tumor progression. Combined with our in vitro results, which showed Oxa-Cyc's ability to directly induce KP tumor cells with immunogenic phenotypes, our findings indicate that Oxa-Cyc-mediated effects on tumor cells instigate a cascade of events that ultimately lead to tumor control. Whether some immunotherapeutics may overcome the limitations of poorly immunogenic chemotherapeutics requires further study. Nonetheless, considering the importance of initial tumor cell drug targeting, it may be possible to further improve clinical outcomes by increasing chemotherapeutic load at the tumor site. This may be achieved by encapsulating drugs within nanoparticles (Peer et al., 2007) or targeting the vasculature (Chauhan et al., 2012).

Second, the Oxa-Cyc-induced antitumor response depends on host $\mathrm{CD} 8^{+} \mathrm{T}$ cells: the drugs

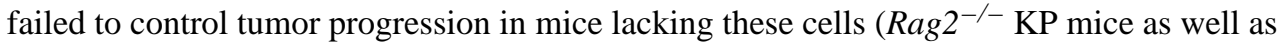
wild-type KP mice depleted with anti- CD8 mAbs). Another study using a genetic mammary cancer model showed that chemotherapeutics can have comparable effects against 
genetically engineered tumors growing in either Rag-competent or Rag-deficient mice (Ciampricotti et al., 2012). These findings suggest that chemotherapy can limit tumor progression without $\mathrm{CD} 8^{+} \mathrm{T}$ cells. Yet, the chemotherapeutics used in the mammary tumor models only delayed tumor growth, whereas accumulating evidence shows that potent tumor infiltration by $\mathrm{CD}^{+} \mathrm{T}$ cells may be key to durably controlling cancer (Gajewski et al., 2013; Tumeh et al., 2014; Spranger et al., 2015). Our study indicates that drug-induced CD8 ${ }^{+} \mathrm{T}$ cell tumor infiltration can contribute to tumor control in genetic mouse models and be harnessed for checkpoint blockade therapy. These findings accord with the observation in a mouse model of castrate-resistant prostate cancer that Oxa can induce $\mathrm{CD} 8^{+} \mathrm{T}$ celldependent tumor eradication (Shalapour et al., 2015).

Third, the drug-induced antitumor T cell response needs intact TLR4 signaling. We observed that TLR4 deficiency prevented Oxa-Cyc from increasing $\mathrm{CD} 8^{+} \mathrm{T}$ cell:Treg cell ratios within the tumor bed and from controlling tumor progression. Accordingly, we found that Oxa-Cyc makes dying tumor cells release HMGB1, which activates TLR4 directly (Apetoh et al., 2007). Also, systemic Oxa-Cyc treatment caused an influx of TLR4 ${ }^{+}$DC-like cells specifically in the tumor stroma. These tumor-infiltrating cells expressed CD103 and thus resembled DCs previously identified as critical stimulators of antitumor $\mathrm{CD} 8^{+} \mathrm{T}$ cell immunity (Broz et al., 2014; Ruffell et al., 2014; Spranger et al., 2015). Our results are in accordance with previous findings that TLR4 can promote DC tumor antigen crosspresentation and $\mathrm{CD} 8^{+} \mathrm{T}$ cell activation following immunogenic tumor cell death (Apetoh et al., 2007) and that tumor-infiltrating DCs can be key regulators of antitumor immunity (Broz et al., 2014). Although the detailed mechanisms shaping successful immune responses against KP tumors require further investigation, the aforementioned findings already provide evidence that shaping these immune responses will require a combination of variables including tumor cell targeting and both the adaptive and innate arms of the immune system. We hypothesize that Oxa-Cyc-induced enrichment of TLR4 ${ }^{+}$antigen-presenting cells in KP tumors precedes and facilitates the local influx of $\mathrm{CD} 8^{+} \mathrm{T}$ cells. Since TLR4 genotype (Casanova et al., 2011) and tumor-associated myeloid cell content (Broz and Krummel, 2015) can vary across individuals and/or tissues, evaluating these innate immune variables may help select treatment options.

Checkpoint blockade therapies have yielded unprecedented clinical benefits against lung and other cancers but on their own may preferentially benefit patients whose tumors are preinfiltrated by $\mathrm{CD}^{+} \mathrm{T}$ cells (Tumeh et al., 2014; Gajewski et al., 2013). We found that therapy-induced $\mathrm{T}$ cell infiltration enabled successful treatment with immune checkpoint inhibition, further indicating that appropriately selected drugs that transform 'cold' tumor tissues into immunologically 'hot' T cell-rich environments can be used to sensitize tumors to immune checkpoint therapy and improve clinical outcome.

Our results provide a proof-of-principle that chemotherapeutics selected for their ability to induce immunogenicity in tumors (e.g. Oxa-Cyc against KP tumors, Doxorubicin against MCA205, and Oxa against CT26) provide additive or synergistic benefits when combined with immune checkpoint blockers. It will be important to explore whether and when other drugs or drug combinations can achieve similar results. For example, it is possible that Oxa alone or Ptax-Carbo also sensitize KP tumors to immune checkpoint blockade or synergize 
with immunotherapy against other cancers. Also, preclinical studies using an ovarian cancer graft model indicate that PD-1 blockade can improve Ptax therapy (Lu et al., 2014) and ongoing clinical trials are testing the potential of Ptax-Carbo to enhance the efficacy of immune checkpoint blocking agents against various cancer types, including NSCLC (Liu et al. J Clin Oncol. 2015;33 (suppl; abstr 8030)); Papadimitrakopoulou et al. J Clin Oncol. 2015;33 (suppl; abstr 8031)).

To achieve tumor sensitization and improved outcomes, we envision two scenarios: 1) reevaluating the chemotherapeutics used in combination with checkpoint blockade agents to specifically include drugs with the potential to induce immunogenic cell death (e.g., Oxa and Cyc as investigated for the KP lung tumor model), and 2) using precision medicine to select drugs with the ability to promote tumor cells' immunogenicity in a given patient. The first approach could provide immediate clinical benefit by expanding the proportion of cancer patients who respond to current immune checkpoint treatments. The second approach involves screening drugs for individual patients and is thus more technically challenging, but because it takes into account that different tumor genetic drivers, tissues of origin and tumor microenvironments can profoundly modify a given drug's efficacy, the drug selection approach may benefit even more patients. The drug-induced readouts could be expanded to study various forms of cell death, including pyroptosis or necroptosis, which could also promote antitumor immunity. Regardless of the approach, drugs that are already FDAapproved could be used to accelerate clinical translation.

\section{EXPERIMENTAL PROCEDURES}

\section{Mice}

$\mathrm{Kras}^{\mathrm{LSL}-\mathrm{G} 12 \mathrm{D} /+} ; \operatorname{Trp} 3^{\text {flox/flox }}(\mathrm{KP})$ mice were used as a conditional mouse model of NSCLC (Cortez-Retamozo et al., 2013). Details about all murine strains and tumor models are provided in the Supplemental Experimental Procedures. All animal experiments were approved by the Massachusetts General Hospital Subcommittee on Research Animal Care, except experiments in BALB/c and MCA205-bearing C57BL/6 mice that were approved by the Ethical Committee of the Gustave Roussy Cancer Campus (Villejuif, France).

\section{Cell Lines}

The lung adenocarcinoma cell line KP1.9 was derived from lung tumors of C57BL/6 KP mice and was kindly provided by Dr. A. Zippelius, University Hospital Basel, Switzerland. The lung adenocarcinoma cell lines KP L1-3, KP L1-5 and KP L2-9 were derived from 129 KP mouse lung tumors and all established in our laboratory. Additional information on further cell lines and cell culture conditions are detailed in the Supplemental Experimental Procedures.

\section{Human Tumor Samples}

Sections from paraffin-embedded biopsies of lung resections ( $\mathrm{n}=76)$ from NSCLC patients with known $K R A S$ and $E G F R$ gene mutation status were obtained from the Department of Pathology at Massachusetts General Hospital. TP53 and CD8 immunohistochemistry were 
performed and evaluated blindly based on defined scoring systems as described in the Supplemental Experimental Procedures.

\section{Micro-Computed Tomography $(\mu \mathrm{CT})$ and Magnet Resonance Imaging (MRI)}

Tumor burden was evaluated by $\mu \mathrm{CT}$ or MRI in anonymized mice. Details of the imaging protocols are provided in the Supplemental Experimental Procedures.

\section{Mouse Histology, Immunohistochemistry (IHC) and Immunofluorescence Microscopy}

Histological analysis of tumor burden in mice was done on formaldehyde-fixed and paraffin-embedded lung tissues using hematoxylin and eosin (H\&E) staining. IHC was done on either paraffin-embedded (HMGB1, cleaved caspase-3, Ki67, CD3, CD4) or frozen (CD8) tissue sections. Detailed information regarding antibody clones and staining procedures are in the Supplemental Experimental Procedures.

\section{Multiphoton Microscopy}

Small lung pieces from tumor-bearing KP mice and tumor-free tissue were fixed, stained and imaged using an Ultima multiphoton microscope (Prairie Technologies). Images were pre-processed in R statistical computing environment using RStudio and stitched/analyzed with Fiji software. More information on staining procedures and image processing are descripted in the Supplemental Experimental Procedures.

\section{HMGB1 and Calreticulin In Vitro Assays}

The KP L1-3, KP L1-5 and KP L2-9 tumor lines were seeded in tissue culture plates before treatment with chemotherapeutic drugs for $24 \mathrm{~h}$ (Dtax, $30 \mu \mathrm{M}$; Carbo, $500 \mu \mathrm{M}$; Oxa, 300 $\mu \mathrm{M}$; Maf, 16.5, 33, $50 \mu \mathrm{g} / \mathrm{ml}$; Mtx, $4 \mu \mathrm{M})$. For the calreticulin assay, the cells were harvested from cell culture plates, fixed and incubated with rabbit anti-calreticulin Ab followed by anti-rabbit AlexaFluor 488 conjugated Ab and investigated by flow cytometry (CyAn ADP analyzer, Beckman Coulter). Detailed assay conditions are provided in the Supplemental Experimental Procedures.

\section{In Vivo Drug Treatments}

KP tumor-bearing mice were either left untreated or received chemotherapy intraperitoneally (i.p.) once a week for three weeks (Oxa, $2.5 \mathrm{mg} / \mathrm{kg}$; Cyc, $50 \mathrm{mg} / \mathrm{kg}$; Ptax, $10 \mathrm{mg} / \mathrm{kg}$; Carbo, $10 \mathrm{mg} / \mathrm{kg}$ ). BALB/c mice bearing CT26 flank tumors and MCA205 flank tumor-bearing C57BL/6 mice received one intratumoral chemotherapeutic drug injection (Oxa, $1.25 \mathrm{mg} / \mathrm{kg}$; Cisplatin, $0.25 \mathrm{mg} / \mathrm{kg}$; Doxorubicin, $2.9 \mathrm{mg} / \mathrm{kg}$ ). mAbs specific for PD-1 (clone 29F.1A12, provided by Dr. G. J. Freeman) and CTLA-4 (clone 9D9, BioXcell) were injected i.p.. Details about in vivo experiments including drug treatment conditions and cell depletion strategies are provided in the Supplemental Experimental Procedures.

\section{Recovery of Cells from Murine Tissues and Flow Cytometry}

Single cell suspensions were prepared from murine lung, spleen and bone marrow and investigated by flow cytometry (LSRII, BD Biosciences). Where indicated, equally sized pieces of tumor stroma and corresponding tumor-free adjacent tissue were isolated 
separately from lungs of Oxa-Cyc-treated or untreated tumor-bearing KP mice. Details about cell recovery strategies and flow cytometry staining procedures including Ab clones and identified cell populations are in the Supplemental Experimental Procedures.

Statistics

Results were expressed as mean \pm SEM. Statistical tests included one-way ANOVA followed by Tukey's or Dunnett's multiple comparison test. When applicable, unpaired one-tailed and two-tailed Student's $t$ tests using Welch's correction for unequal variances were used.

Comparison of survival curves was performed with the Log-rank Mantel-Cox test. $P$ values of 0.05 or less were considered to denote significance $(* P<0.05$; $* * P<0.01 ; * * * P<0.001$; $* * * * P<0.0001 ;$ ns, not significant).

\section{Supplementary Material}

Refer to Web version on PubMed Central for supplementary material.

\section{Acknowledgments}

The authors thank the members of the Hope Babette Tang Histology Facility at the Koch Institute Swanson Biotechnology Center for technical support. This work was supported in part by the Samana Cay MGH Research Scholar Fund (to M.J.P.), NIH grants P50-CA86355 and R01-AI084880 (to M.J.P.), U54-CA126515 (to R.W.), 5U54CA163125 (to G.J.F.) and 5U54-CA163109 and the Howard Hughes Medical Institute (to R.O.H.). C.P. was supported by the Deutsche Forschungsgemeinschaft (DFG) PF809/1-1, C.E. by the Boehringer Ingelheim Fonds and S.R. by the DFG RI2408/1-1.

\section{REFERENCES}

Apetoh L, Ghiringhelli F, Tesniere A, Obeid M, Ortiz C, Criollo A, Mignot G, Maiuri MC, Ullrich E, Saulnier P, Yang H, Amigorena S, Ryffel B, Barrat FJ, Saftig P, Levi F, Lidereau R, Nogues C, Mira JP, Chompret A, Joulin V, Clavel-Chapelon F, Bourhis J, André F, Delaloge S, Tursz T, Kroemer G, Zitvogel L. Toll-like receptor 4-dependent contribution of the immune system to anticancer chemotherapy and radiotherapy. Nat Med. 2007; 13:1050-1059. [PubMed: 17704786]

Broz ML, Binnewies M, Boldajipour B, Nelson AE, Pollack JL, Erle DJ, Barczak A, Rosenblum MD, Daud A, Barber DL, Amigorena S, Van't Veer LJ, Sperling AI, Wolf DM, Krummel MF. Dissecting the tumor myeloid compartment reveals rare activating antigen-presenting cells critical for T cell immunity. Cancer Cell. 2014; 26:638-652. [PubMed: 25446897]

Broz ML, Krummel MF. The emerging understanding of myeloid cells as partners and targets in tumor rejection. Cancer Immunol Res. 2015; 3:313-319. [PubMed: 25847968]

Casanova JL, Abel L, Quintana-Murci L. Human TLRs and IL-1Rs in host defense: natural insights from evolutionary, epidemiological, and clinical genetics. Annu Rev Immunol. 2011; 29:447-491. [PubMed: 21219179]

Chauhan VP, Stylianopoulos T, Martin JD, Popović Z, Chen O, Kamoun WS, Bawendi MG, Fukumura D, Jain RK. Normalization of tumour blood vessels improves the delivery of nanomedicines in a size-dependent manner. Nat Nanotechnol. 2012; 7:383-388. [PubMed: 22484912]

Ciampricotti M, Hau CS, Doornebal CW, Jonkers J, de Visser KE. Chemotherapy response of spontaneous mammary tumors is independent of the adaptive immune system. Nat Med. 2012; 18:344-346. author reply 346. [PubMed: 22395693]

Cortez-Retamozo V, Etzrodt M, Newton A, Rauch PJ, Chudnovskiy A, Berger C, Ryan RJ, Iwamoto Y, Marinelli B, Gorbatov R, Forghani R, Novobrantseva TI, Koteliansky V, Figueiredo JL, Chen JW, Anderson DG, Nahrendorf M, Swirski FK, Weissleder R, Pittet MJ. Origins of tumorassociated macrophages and neutrophils. Proc Natl Acad Sci U S A. 2012; 109:2491-2496. [PubMed: 22308361] 
Cortez-Retamozo V, Etzrodt M, Newton A, Ryan R, Pucci F, Sio SW, Kuswanto W, Rauch PJ, Chudnovskiy A, Iwamoto Y, Kohler R, Marinelli B, Gorbatov R, Wojtkiewicz G, Panizzi P, MinoKenudson M, Forghani R, Figueiredo JL, Chen JW, Xavier R, Swirski FK, Nahrendorf M, Weissleder R, Pittet MJ. Angiotensin II drives the production of tumor-promoting macrophages. Immunity. 2013; 38:296-308. [PubMed: 23333075]

De Palma M, Lewis CE. Macrophage regulation of tumor responses to anticancer therapies. Cancer Cell. 2013; 23:277-286. [PubMed: 23518347]

DuPage M, Cheung AF, Mazumdar C, Winslow MM, Bronson R, Schmidt LM, Crowley D, Chen J, Jacks T. Endogenous T cell responses to antigens expressed in lung adenocarcinomas delay malignant tumor progression. Cancer Cell. 2011; 19:72-85. [PubMed: 21251614]

Fridman WH, Pages F, Sautes-Fridman C, Galon J. The immune contexture in human tumours: impact on clinical outcome. Nat Rev Cancer. 2012; 12:298-306. [PubMed: 22419253]

Gajewski TF, Schreiber H, Fu YX. Innate and adaptive immune cells in the tumor microenvironment. Nat Immunol. 2013; 14:1014-1022. [PubMed: 24048123]

Gao Q, Qiu SJ, Fan J, Zhou J, Wang XY, Xiao YS, Xu Y, Li YW, Tang ZY. Intratumoral balance of regulatory and cytotoxic $T$ cells is associated with prognosis of hepatocellular carcinoma after resection. J Clin Oncol. 2007; 25:2586-2593. [PubMed: 17577038]

Ghiringhelli F, Larmonier N, Schmitt E, Parcellier A, Cathelin D, Garrido C, Chauffert B, Solary E, Bonnotte B, Martin F. CD4+CD25+ regulatory T cells suppress tumor immunity but are sensitive to cyclophosphamide which allows immunotherapy of established tumors to be curative. Eur J Immunol. 2004; 34:336-344. [PubMed: 14768038]

Gou HF, Huang J, Shi HS, Chen XC, Wang YS. Chemo-immunotherapy with oxaliplatin and interleukin-7 inhibits colon cancer metastasis in mice. PLoS One. 2014; 9:e85789. [PubMed: 24465710]

Gubin MM, Zhang X, Schuster H, Caron E, Ward JP, Noguchi T, Ivanova Y, Hundal J, Arthur CD, Krebber WJ, Mulder GE, Toebes M, Vesely MD, Lam SS, Korman AJ, Allison JP, Freeman GJ, Sharpe AH, Pearce EL, Schumacher TN, Aebersold R, Rammensee HG, Melief CJ, Mardis ER, Gillanders WE, Artyomov MN, Schreiber RD. Checkpoint blockade cancer immunotherapy targets tumour-specific mutant antigens. Nature. 2014; 515:577-581. [PubMed: 25428507]

Herbst RS, Soria JC, Kowanetz M, Fine GD, Hamid O, Gordon MS, Sosman JA, McDermott DF, Powderly JD, Gettinger SN, Kohrt HE, Horn L, Lawrence DP, Rost S, Leabman M, Xiao Y, Mokatrin A, Koeppen H, Hegde PS, Mellman I, Chen DS, Hodi FS. Predictive correlates of response to the anti-PD-L1 antibody MPDL3280A in cancer patients. Nature. 2014; 515:563-567. [PubMed: 25428504]

Klug F, Prakash H, Huber PE, Seibel T, Bender N, Halama N, Pfirschke C, Voss RH, Timke C, Umansky L, Klapproth K, Schakel K, Garbi N, Jager D, Weitz J, Schmitz-Winnenthal H, Hammerling GJ, Beckhove P. Low-dose irradiation programs macrophage differentiation to an iNOS(+)/M1 phenotype that orchestrates effective T cell immunotherapy. Cancer Cell. 2013; 24:589-602. [PubMed: 24209604]

Kroemer G, Galluzzi L, Kepp O, Zitvogel L. Immunogenic cell death in cancer therapy. Annu Rev Immunol. 2013; 31:51-72. [PubMed: 23157435]

Lu L, Xu X, Zhang B, Zhang R, Ji H, Wang X. Combined PD-1 blockade and GITR triggering induce a potent antitumor immunity in murine cancer models and synergizes with chemotherapeutic drugs. J Transl Med. 2014; 12:36. [PubMed: 24502656]

Lutsiak ME, Semnani RT, De Pascalis R, Kashmiri SV, Schlom J, Sabzevari H. Inhibition of CD4(+)25+ T regulatory cell function implicated in enhanced immune response by low-dose cyclophosphamide. Blood. 2005; 105:2862-2868. [PubMed: 15591121]

Olive KP, Jacobetz MA, Davidson CJ, Gopinathan A, McIntyre D, Honess D, Madhu B, Goldgraben MA, Caldwell ME, Allard D, Frese KK, Denicola G, Feig C, Combs C, Winter SP, IrelandZecchini H, Reichelt S, Howat WJ, Chang A, Dhara M, Wang L, Ruckert F, Grutzmann R, Pilarsky C, Izeradjene K, Hingorani SR, Huang P, Davies SE, Plunkett W, Egorin M, Hruban RH, Whitebread N, McGovern K, Adams J, Iacobuzio-Donahue C, Griffiths J, Tuveson DA. Inhibition of Hedgehog signaling enhances delivery of chemotherapy in a mouse model of pancreatic cancer. Science. 2009; 324:1457-1461. [PubMed: 19460966] 
Oliver TG, Mercer KL, Sayles LC, Burke JR, Mendus D, Lovejoy KS, Cheng MH, Subramanian A, Mu D, Powers S, Crowley D, Bronson RT, Whittaker CA, Bhutkar A, Lippard SJ, Golub T, Thomale J, Jacks T, Sweet-Cordero EA. Chronic cisplatin treatment promotes enhanced damage repair and tumor progression in a mouse model of lung cancer. Genes Dev. 2010; 24:837-852. [PubMed: 20395368]

Peer D, Karp JM, Hong S, Farokhzad OC, Margalit R, Langer R. Nanocarriers as an emerging platform for cancer therapy. Nat Nanotechnol. 2007; 2:751-760. [PubMed: 18654426]

Postow MA, Chesney J, Pavlick AC, Robert C, Grossmann K, McDermott D, Linette GP, Meyer N, Giguere JK, Agarwala SS, Shaheen M, Ernstoff MS, Minor D, Salama AK, Taylor M, Ott PA, Rollin LM, Horak C, Gagnier P, Wolchok JD, Hodi FS. Nivolumab and Ipilimumab versus Ipilimumab in Untreated Melanoma. N Engl J Med. 2015

Rizvi NA, Hellmann MD, Snyder A, Kvistborg P, Makarov V, Havel JJ, Lee W, Yuan J, Wong P, Ho TS, Miller ML, Rekhtman N, Moreira AL, Ibrahim F, Bruggeman C, Gasmi B, Zappasodi R, Maeda Y, Sander C, Garon EB, Merghoub T, Wolchok JD, Schumacher TN, Chan TA. Cancer immunology. Mutational landscape determines sensitivity to PD-1 blockade in non-small cell lung cancer. Science. 2015; 348:124-128. [PubMed: 25765070]

Rooney MS, Shukla SA, Wu CJ, Getz G, Hacohen N. Molecular and genetic properties of tumors associated with local immune cytolytic activity. Cell. 2015; 160:48-61. [PubMed: 25594174]

Ruffell B, Chang-Strachan D, Chan V, Rosenbusch A, Ho CM, Pryer N, Daniel D, Hwang ES, Rugo HS, Coussens LM. Macrophage IL-10 blocks CD8+ T cell-dependent responses to chemotherapy by suppressing IL-12 expression in intratumoral dendritic cells. Cancer Cell. 2014; 26:623-637. [PubMed: 25446896]

Sato E, Olson SH, Ahn J, Bundy B, Nishikawa H, Qian F, Jungbluth AA, Frosina D, Gnjatic S, Ambrosone C, Kepner J, Odunsi T, Ritter G, Lele S, Chen YT, Ohtani H, Old LJ, Odunsi K. Intraepithelial CD8+ tumor-infiltrating lymphocytes and a high CD8+/regulatory $\mathrm{T}$ cell ratio are associated with favorable prognosis in ovarian cancer. Proc Natl Acad Sci U S A. 2005; 102:18538-18543. [PubMed: 16344461]

Schiavoni G, Sistigu A, Valentini M, Mattei F, Sestili P, Spadaro F, Sanchez M, Lorenzi S, D’Urso MT, Belardelli F, Gabriele L, Proietti E, Bracci L. Cyclophosphamide synergizes with type I interferons through systemic dendritic cell reactivation and induction of immunogenic tumor apoptosis. Cancer Res. 2011; 71:768-778. [PubMed: 21156650]

Schreiber RD, Old LJ, Smyth MJ. Cancer immunoediting: integrating immunity's roles in cancer suppression and promotion. Science. 2011; 331:1565-1570. [PubMed: 21436444]

Schumacher TN, Schreiber RD. Neoantigens in cancer immunotherapy. Science. 2015; 348:69-74. [PubMed: 25838375]

Shalapour S, Font-Burgada J, Di Caro G, Zhong Z, Sanchez-Lopez E, Dhar D, Willimsky G, Ammirante M, Strasner A, Hansel DE, Jamieson C, Kane CJ, Klatte T, Birner P, Kenner L, Karin M. Immunosuppressive plasma cells impede T-cell-dependent immunogenic chemotherapy. Nature. 2015; 521:94-98. [PubMed: 25924065]

Sharma P, Allison JP. The future of immune checkpoint therapy. Science. 2015; 348:56-61. [PubMed: 25838373]

Spranger S, Bao R, Gajewski TF. Melanoma-intrinsic $\beta$-catenin signalling prevents anti-tumour immunity. Nature. 2015; 523:231-235. [PubMed: 25970248]

Tesniere A, Schlemmer F, Boige V, Kepp O, Martins I, Ghiringhelli F, Aymeric L, Michaud M, Apetoh L, Barault L, Mendiboure J, Pignon JP, Jooste V, van Endert P, Ducreux M, Zitvogel L, Piard F, Kroemer G. Immunogenic death of colon cancer cells treated with oxaliplatin. Oncogene. 2010; 29:482-491. [PubMed: 19881547]

Topalian SL, Drake CG, Pardoll DM. Immune Checkpoint Blockade: A Common Denominator Approach to Cancer Therapy. Cancer Cell. 2015; 27:450-461. [PubMed: 25858804]

Topalian SL, Hodi FS, Brahmer JR, Gettinger SN, Smith DC, McDermott DF, Powderly JD, Carvajal RD, Sosman JA, Atkins MB, Leming PD, Spigel DR, Antonia SJ, Horn L, Drake CG, Pardoll DM, Chen L, Sharfman WH, Anders RA, Taube JM, McMiller TL, Xu H, Korman AJ, Jure-Kunkel M, Agrawal S, McDonald D, Kollia GD, Gupta A, Wigginton JM, Sznol M. Safety, activity, and immune correlates of anti-PD-1 antibody in cancer. N Engl J Med. 2012; 366:2443-2454. [PubMed: 22658127] 
Torre LA, Bray F, Siegel RL, Ferlay J, Lortet-Tieulent J, Jemal A. Global cancer statistics, 2012. CA Cancer J Clin. 2015; 65:87-108. [PubMed: 25651787]

Tumeh PC, Harview CL, Yearley JH, Shintaku IP, Taylor EJ, Robert L, Chmielowski B, Spasic M, Henry G, Ciobanu V, West AN, Carmona M, Kivork C, Seja E, Cherry G, Gutierrez AJ, Grogan TR, Mateus C, Tomasic G, Glaspy JA, Emerson RO, Robins H, Pierce RH, Elashoff DA, Robert C, Ribas A. PD-1 blockade induces responses by inhibiting adaptive immune resistance. Nature. 2014; 515:568-571. [PubMed: 25428505]

Wolchok JD, Kluger H, Callahan MK, Postow MA, Rizvi NA, Lesokhin AM, Segal NH, Ariyan CE, Gordon RA, Reed K, Burke MM, Caldwell A, Kronenberg SA, Agunwamba BU, Zhang X, Lowy I, Inzunza HD, Feely W, Horak CE, Hong Q, Korman AJ, Wigginton JM, Gupta A, Sznol M. Nivolumab plus ipilimumab in advanced melanoma. N Engl J Med. 2013; 369:122-133. [PubMed: 23724867]

Zitvogel L, Galluzzi L, Smyth MJ, Kroemer G. Mechanism of action of conventional and targeted anticancer therapies: reinstating immunosurveillance. Immunity. 2013; 39:74-88. [PubMed: 23890065] 


\section{Highlights}

- Kras/Trp53 mutant tumors lack $\mathrm{CD}^{+} \mathrm{T}$ cells and resist chemo- and immunotherapies

- Immunogenic chemotherapy elicits tumor T cell infiltration and controls cancer growth

- Tumor control requires $\mathrm{CD} 8^{+} \mathrm{T}$ cells, $\mathrm{TLR} 4^{+}$cells and drug actions on cancer cells

- T cell influx sensitizes tumors to checkpoint inhibition and durably controls cancer 
A
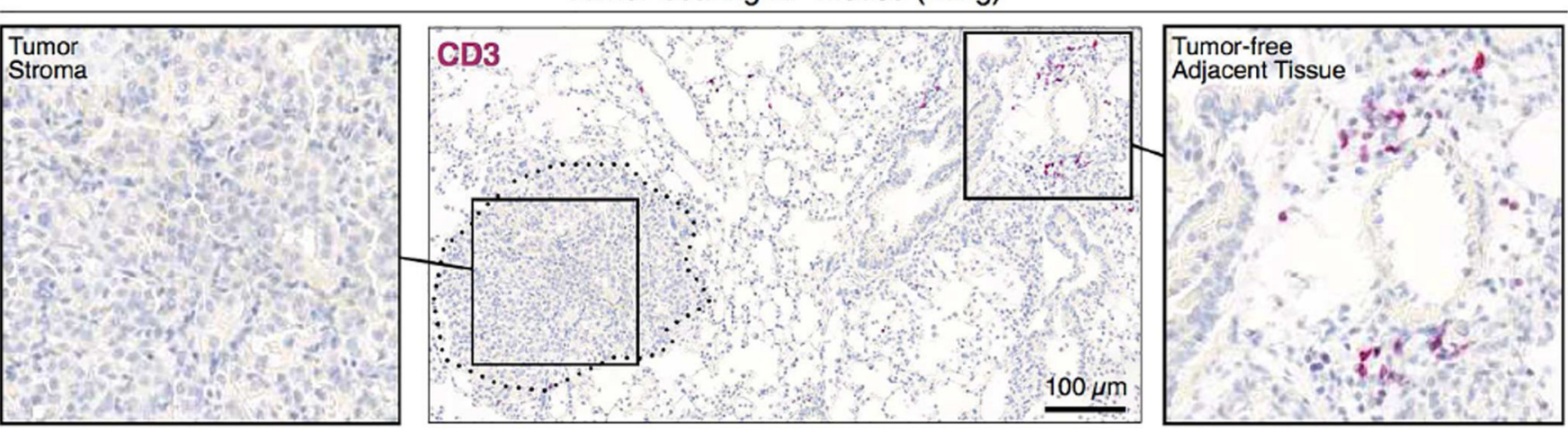

B

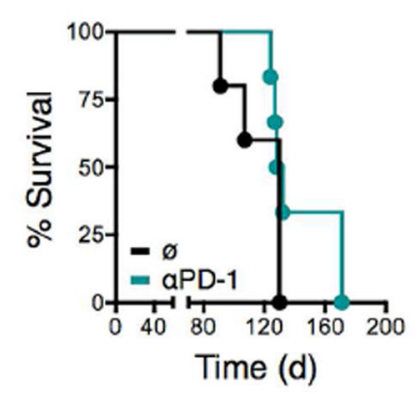

C

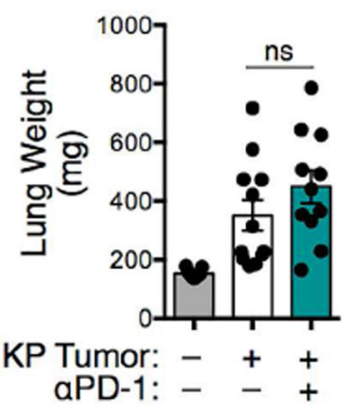

D
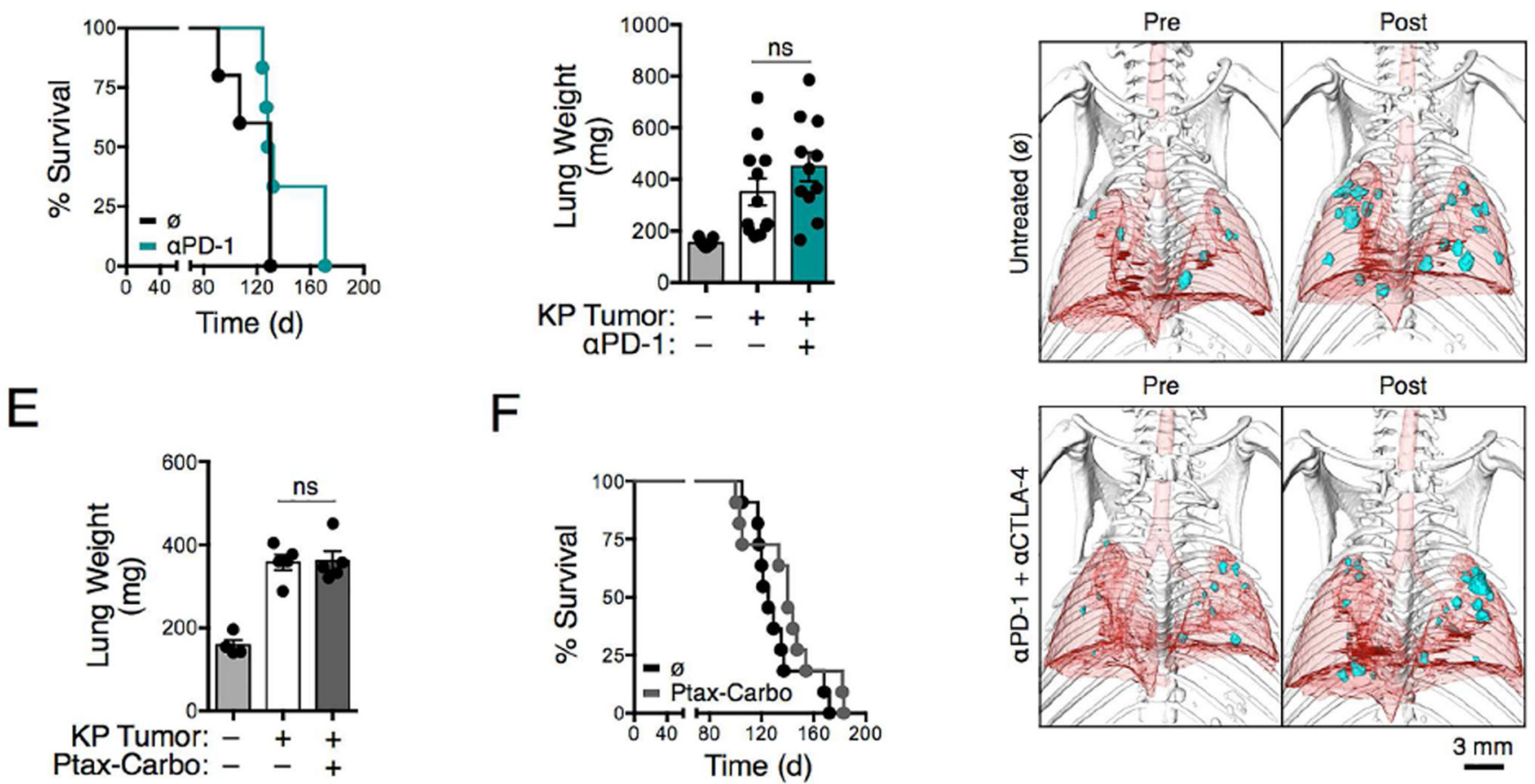

Figure 1. Kras-Trp53-mutated lung adenocarcinomas are inadequately infiltrated by $\mathbf{T}$ cells and resist current treatment options

A) Immunohistochemistry of $\mathrm{CD}^{+}$cells in KP lung tumor tissue on day 66 after tumor initiation. (B) Survival of KP mice treated or not with anti-PD-1 (aPD-1) mAbs (n=5-6 mice per group). Tumors were induced on day 0 by intratracheal intubation and inhalation (i.t.) of an adenovirus expressing Cre recombinase (AdCre). Mice were treated every third or fourth day with anti-PD-1 Abs intraperitoneally (i.p.) starting from day 60 to 86. (C) Lung weight as proxy for tumor burden (Cortez-Retamozo et al., 2012) measured on day 44 in mice bearing orthotopic KP1.9 tumors and treated or not with anti-PD-1 mAbs every third or forth day from day 25 to 42 after tumor cell injection (n=9-12 mice per group). (D) Microcomputed tomography of KP-OVA mice both pre- (day 122) and post-treatment (day 146) with no antibody $(\varnothing)$ or with anti-PD-1 and anti-CTLA-4 (aPD-1 + aCTLA-4) mAbs. Tumors were induced with a lentiviral vector containing OVA peptide sequences (LucOS) 
i.t. and $\mathrm{mAb}$ treatment was performed every second or third day from day 133 to 145 . (E) Lung weight ( $\mathrm{n}=4-5$ mice per group) and $(\mathbf{F})$ survival ( $\mathrm{n}=11$ mice per group) of KP mice treated or not with paclitaxel and carboplatin (Ptax-Carbo). Mice were treated once a week for three weeks starting on day 63 post i.t. tumor initiation and lungs analyzed three days after the last drug injection. For survival studies, Ptax-Carbo was injected i.p. once a week. ns, not significant. See also Figure S1. 


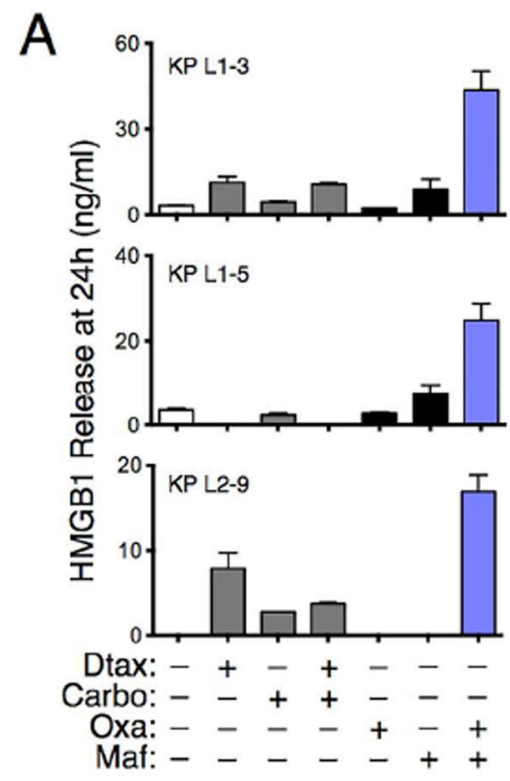

B

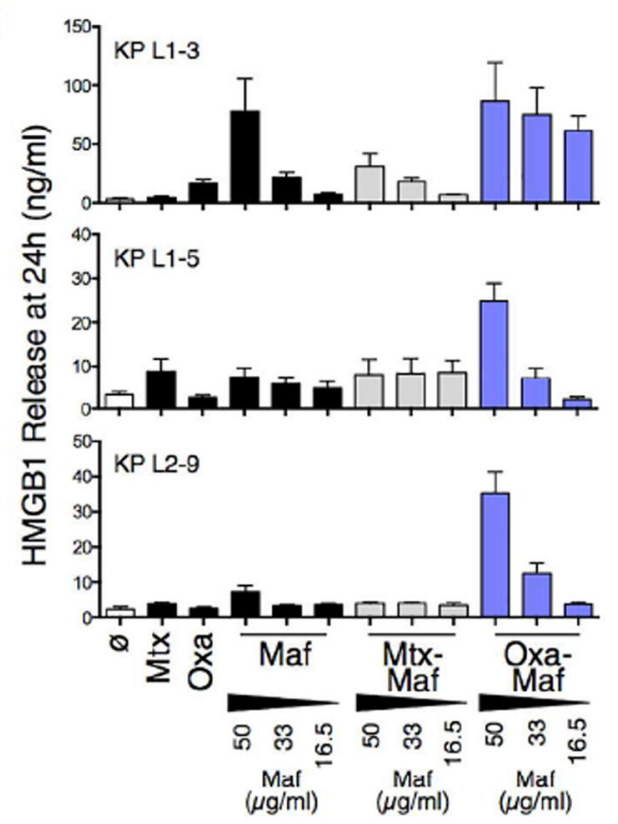

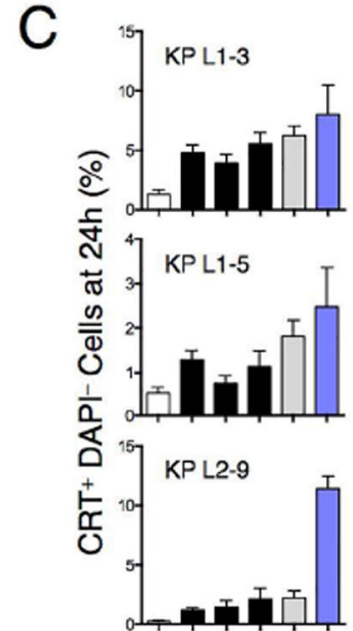

Mtx: -+--+Oxa: --+--+ Maf: ---++

Ptax-Carbo
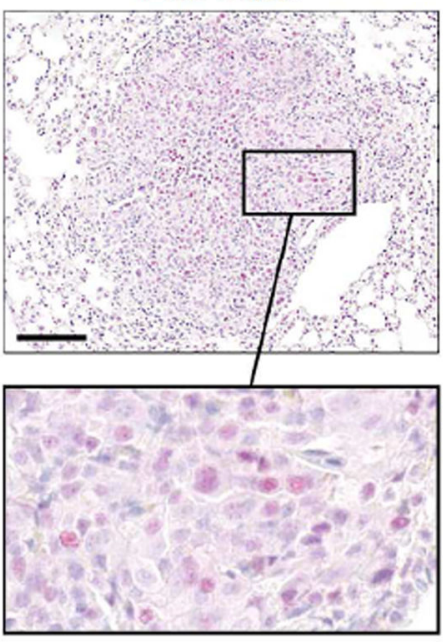

Oxa-Cyc

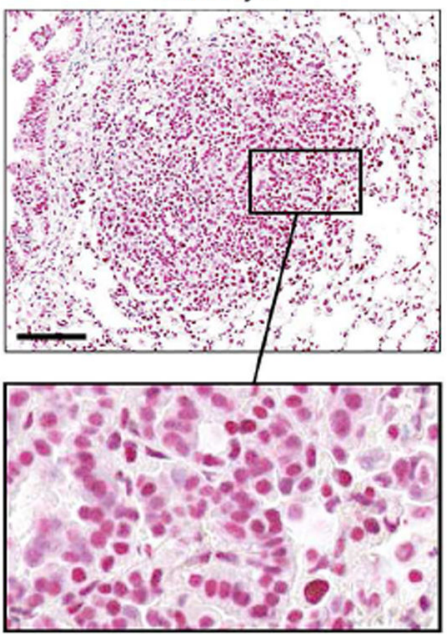

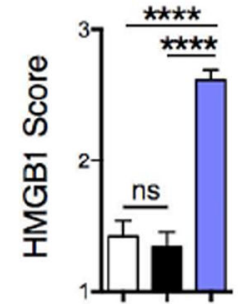

KP Tumor: +++ Ptax-Carbo: -+

Oxa-Cyc: --+

Figure 2. Selected drugs induce KP tumor cell immune phenotypes

A) In vitro $\mathrm{HMGB} 1$ release by three KP tumor cell lines, generated from lung tissue of tumor-bearing KP mice, in response to various chemotherapeutic drug combinations as determined by ELISA ( $\mathrm{n}=2-4$ replicates). (B) HMGB1 release by tumor cell lines treated with Mitoxantrone $(4 \mu \mathrm{M})$, Oxaliplatin $(300 \mu \mathrm{M})$ and/or Mafosfamide at different concentrations $(16.5,33$ or $50 \mu \mathrm{g} / \mathrm{ml})(\mathrm{n}=4$ replicates). (C) Calreticulin exposure by tumor cell lines treated with defined drug combinations measured by flow cytometry $(n=6$ replicates). (D) HMGB1 immunohistochemistry (left) and scoring (right) in lung tumor nodules $(n=39-48)$ of KP mice untreated $(\varnothing)$ or treated with Ptax-Carbo or Oxa-Cyc (See also Figure S2C for comparable images). Scale bars: $100 \mu \mathrm{m}$. $* * * * P<0.0001$; ns, not significant; CRT, Calreticulin; Carbo, Carboplatin; Cyc, Cyclophosphamide; Dtax, Docetaxel; Maf, Mafosfamide; Mtx, Mitoxantrone; Oxa, Oxaliplatin; Ptax, Paclitaxel. 

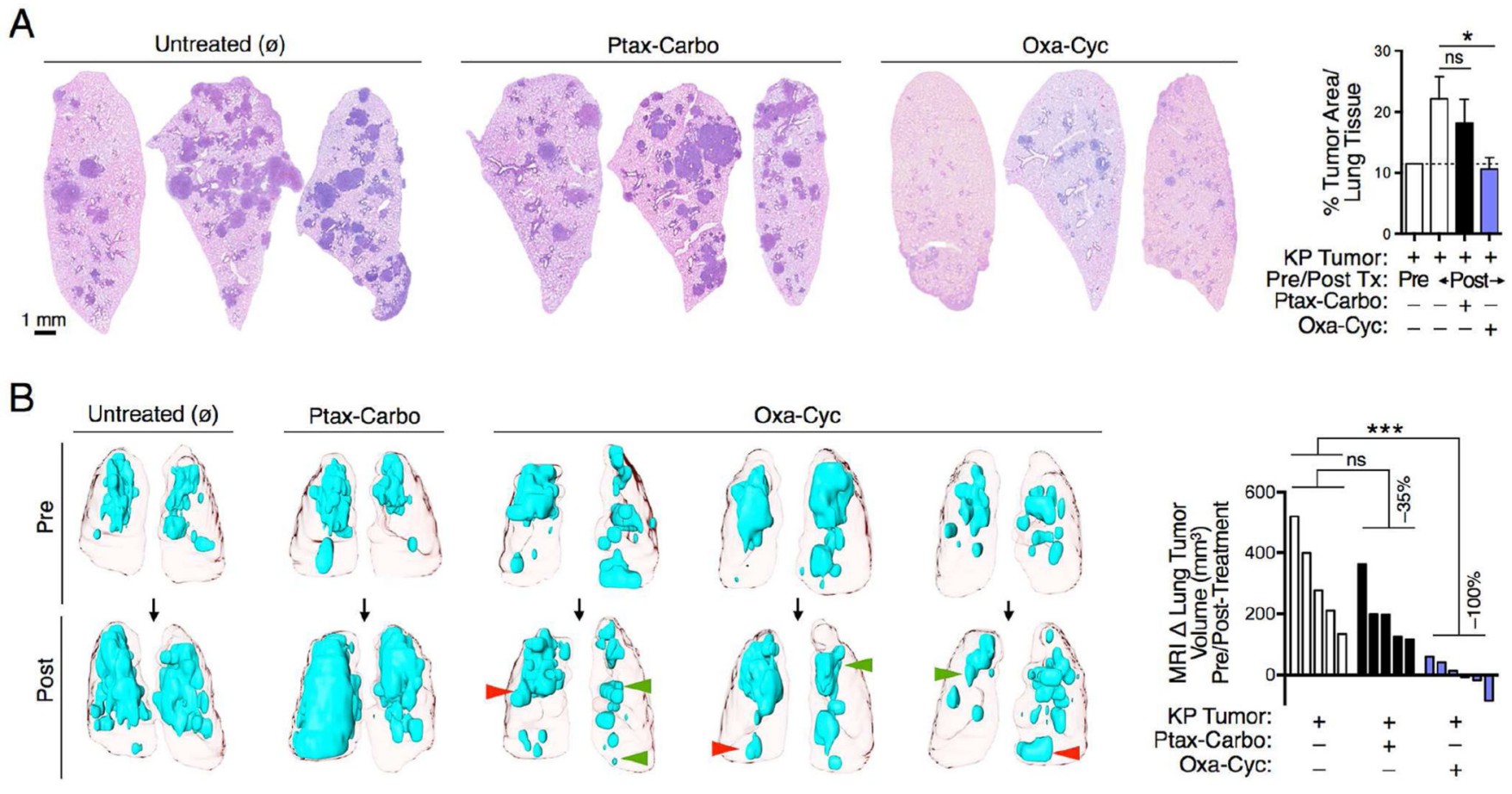

Figure 3. Drugs selected for their immunogenicity delay KP cancer progression

A) Lung tumor burden identification (left) and quantification (right) by hematoxylin and eosin (H\&E) staining. Mice were treated with Ptax-Carbo or Oxa-Cyc after establishment of lung adenocarcinomas for a duration of 3 weeks. (B) Lung tumor detection by noninvasive magnetic resonance imaging both pre- and post-treatment as in (A) (left) and quantification of tumor progression, defined as delta tumor volume in $\mathrm{mm}^{3}$, in individual mice over time (right, $\mathrm{n}=5-6$ mice per group). Red and green arrowheads show progressing and regressing tumor areas, respectively. $* P<0.05$; $* * * P<0.001$; ns, not significant; Tx, treatment; Carbo, Carboplatin; Cyc, Cyclophosphamide; Oxa, Oxaliplatin; Ptax, Paclitaxel. See also Figure S3. 
A

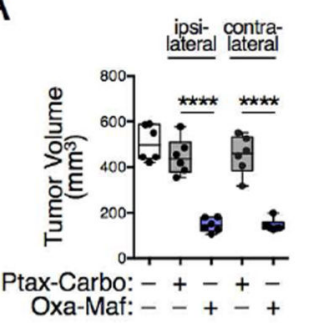

B

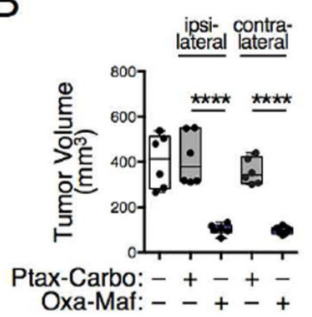

C

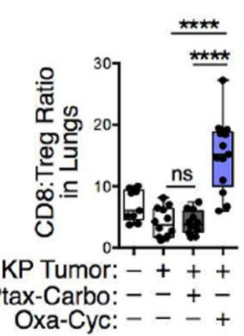

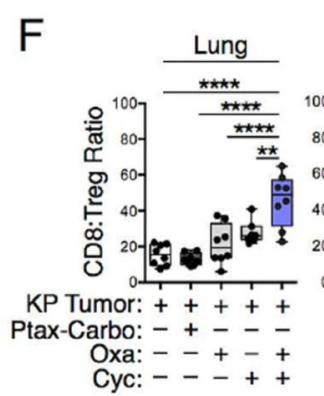

G

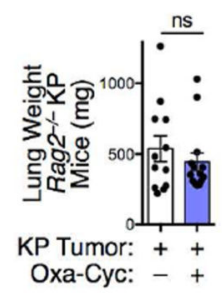

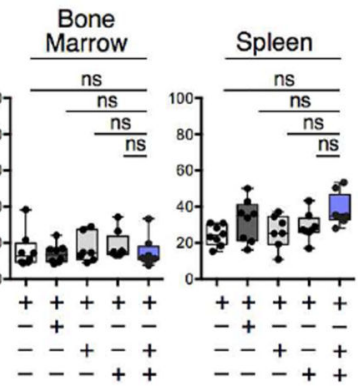

D

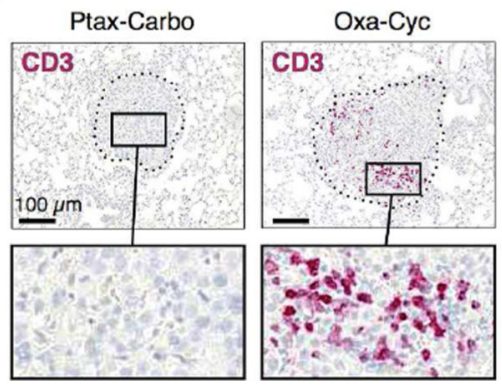

$E$

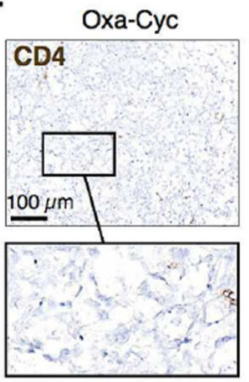

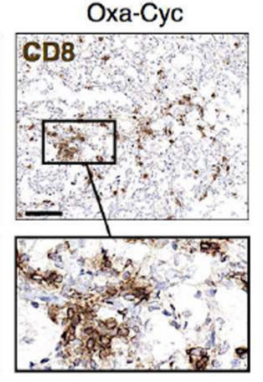

$\mathrm{H}$

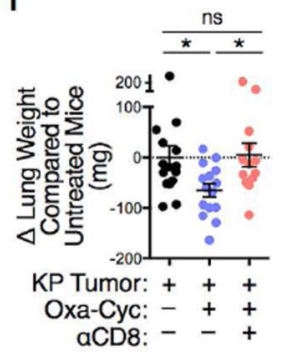

Figure 4. Drug-induced tumor control involves adaptive immunity

A and B) Impact of vaccinations with Ptax-Carbo- or Oxa-Maf-killed tumor cells on growth of KP1.9 tumors injected on day 0 ipsi- or contralaterally to the vaccination sites. Mice were injected with in vitro killed tumor cells on day $-8,-4,-2,5$ and 12 (A) or only received prophylactic vaccination on day $-8,-4$ and -2 (B). Tumor burden was analyzed on day 19 (A) or day 14 (B), respectively ( $\mathrm{n}=6$ mice per group). (C) $\mathrm{CD}^{+} \mathrm{T}$ cell:Treg cell ratio in lungs of KP mice assessed by flow cytometry at 3 week post-treatment with Ptax-Carbo or Oxa-Cyc (n=9-13 mice per group). (D) CD3 immunohistochemistry of representative lung tumor sections from KP mice treated as in (C) (see Figure S4A for comparable images). Scale bars: $100 \mu \mathrm{m}$. (E) CD4 and CD8 immunohistochemistry of lung tumor tissue from Oxa-Cyc-treated KP mice (see Figure S4C for comparable images). Scale bars: $100 \mu \mathrm{m}$. (F) $\mathrm{CD}^{+} \mathrm{T}$ cell:Treg cell ratios assessed by flow cytometry in lung, bone marrow and spleen of KP1.9 lung tumor-bearing mice left untreated or that received Ptax-Carbo, Oxa, Cyc or OxaCyc ( $\mathrm{n}=7-8$ mice per group). (G) Lung weight of $\mathrm{Rag}^{-/-} \mathrm{KP}$ mice treated or not with OxaCyc ( $n=12-14$ mice per group). (H) Lung weight of Oxa-Cyc-treated KP mice that received CD8 depleting mAbs (aCD8, $\mathrm{n}=13-15$ mice per group). $* P<0.05 ; * * P<0.01 ; * * * *<$ 0.0001; ns, not significant. See also Figure S4. 


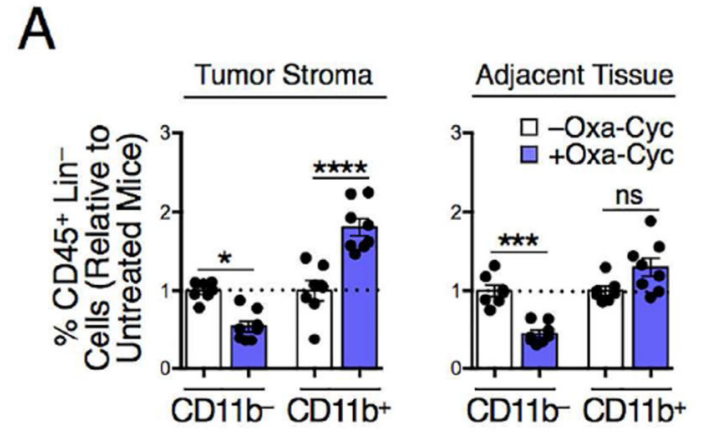

B
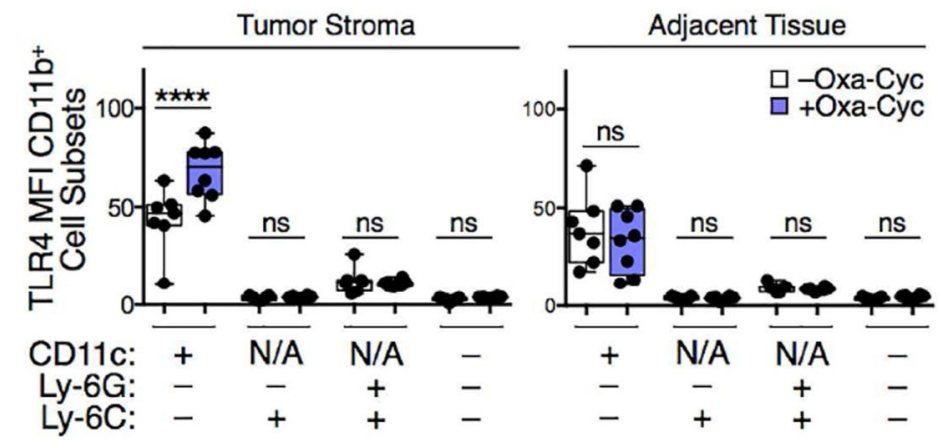

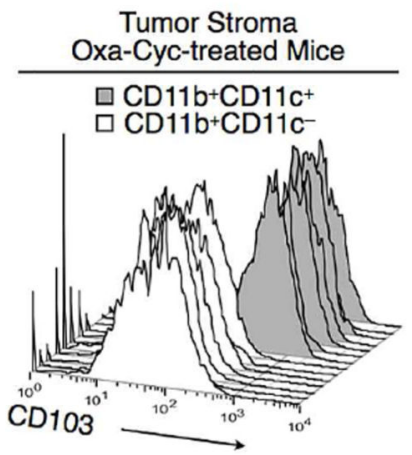

D
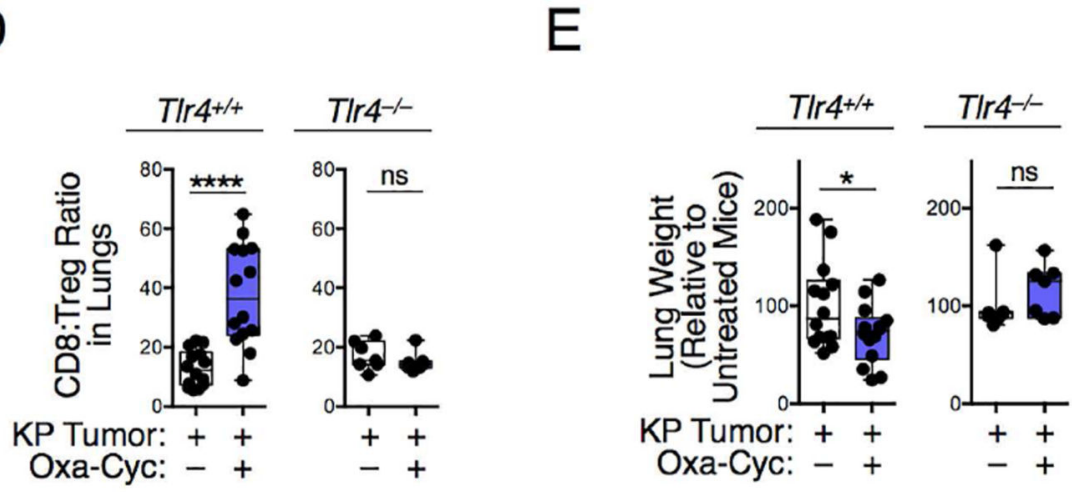

Figure 5. Drug-induced tumor control involves innate immunity and TLR4 signaling A) $\mathrm{CD}_{11 b^{-}}$and CD11 $\mathrm{b}^{+}$cells in lung tissue biopsies of KP mice that received Oxa-Cyc or were left untreated ( $\mathrm{n}=7-8$ mice per group). Lung tissue biopsies of tumor and tumor-free adjacent tissues were investigated in parallel. (B) TLR4 mean fluorescence intensity (MFI) of $\mathrm{CD} 11 \mathrm{~b}^{+}$cell subsets in tumor and tumor-free lung tissues of Oxa-Cyc treated or untreated KP mice ( $\mathrm{n}=7-8$ mice per group). (C) CD103 phenotype of $\mathrm{CD} 11 \mathrm{~b}^{+} \mathrm{CD} 11 \mathrm{c}^{-}$and $\mathrm{CD} 11 \mathrm{~b}^{+} \mathrm{CD} 11 \mathrm{c}^{+}$cells in tumor stroma of Oxa-Cyc-treated mice ( $\mathrm{n}=7$ mice per group). (D and E) Lung $\mathrm{CD}^{+} \mathrm{T}$ cell:Treg cell ratio (D) and lung weight (E) of KP1.9 tumor-bearing $T l r 4^{+/+}$and $T l r 4^{-/-}$mice treated or not with Oxa-Cyc (n=7-14 mice per group). Lineage (Lin) defined as (B220/CD49b/CD90.2/Ter119) ${ }^{+}$. $* P<0.05$; *** $P<0.001$; **** $P<$ $0.0001 ;$ ns, not significant; N/A, not applicable. 
A

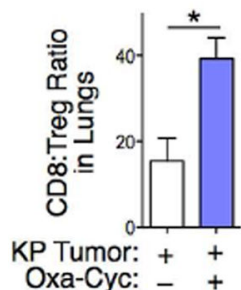

B

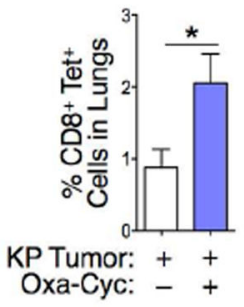

C

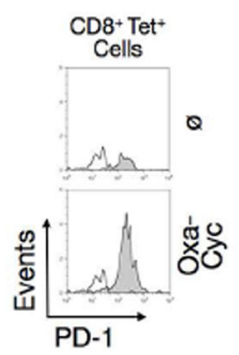

D

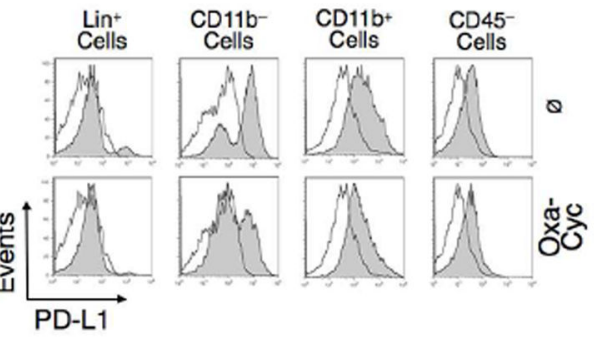

E

○ $\odot$ Oxa-Cyc $\bigcirc \mathrm{aPD}-1+\mathrm{aCTLA}-4$ Оxa-Cyc + aPD-1 + aCTLA-4

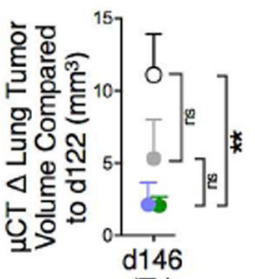

$\left(\mathrm{T}_{1}\right)$

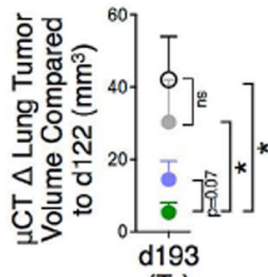

$\left(T_{2}\right)$

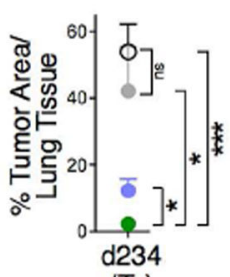

$\left(\mathrm{T}_{3}\right)$
F
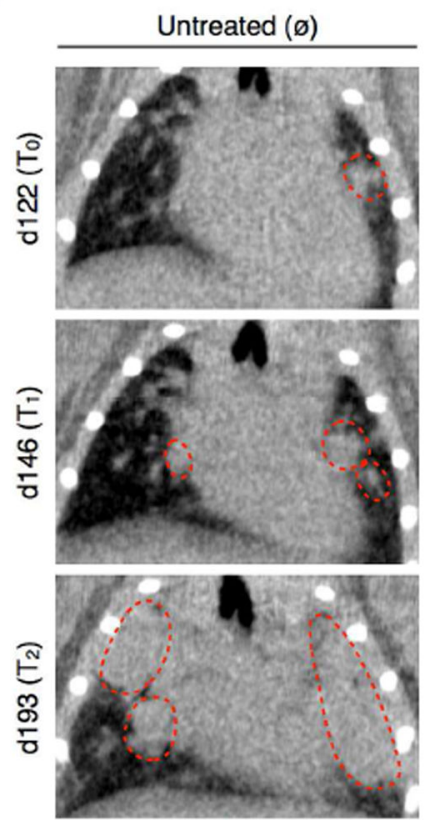

\section{Oxa-Cyc + aPD-1 + aCTLA-4}
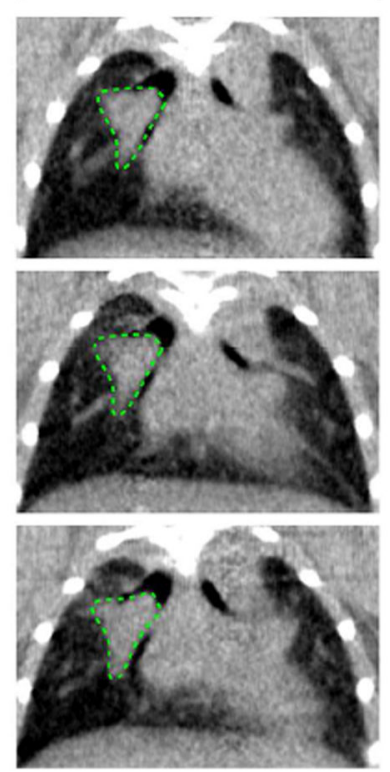

G

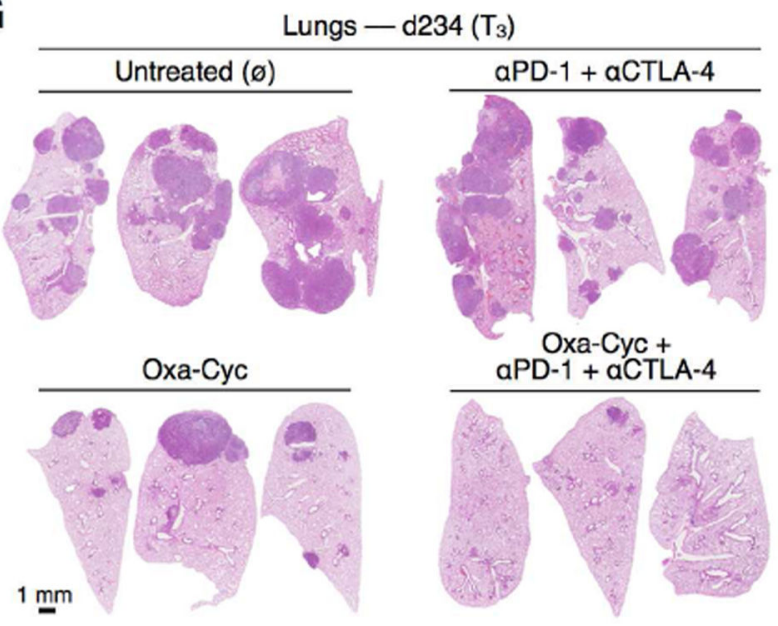

$\mathrm{H}$ Tumor Nodules $-\mathrm{d} 234\left(\mathrm{~T}_{3}\right)$

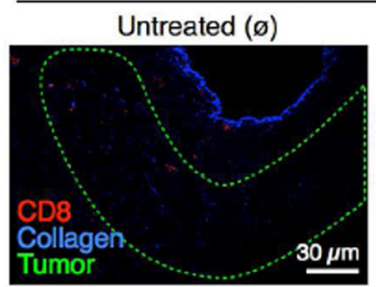

Oxa-Cyc

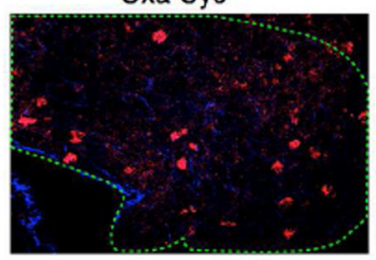

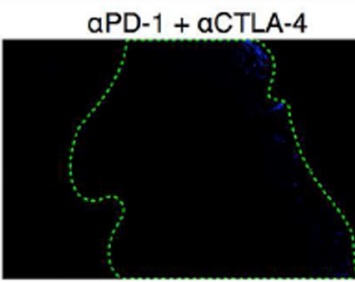

$\mathrm{Oxa}-\mathrm{Cyc}+$ aPD-1 + aCTLA-4

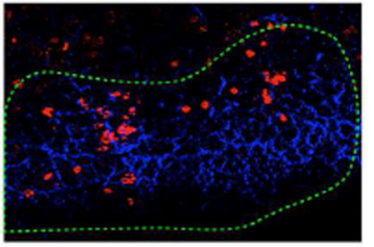

Figure 6. Drug-induced tumor infiltration by $\mathrm{CD8}^{+} \mathrm{T}$ cells sensitizes lung adenocarcinomas to immune checkpoint therapy

A to D) Lung $\mathrm{CD}^{+} \mathrm{T}$ cell:Treg cell ratio (A), percent of OVA-specific $\mathrm{CD}^{+}{ }^{+} \mathrm{T}$ cells in lungs (B), PD-1 expression by these cells (C) and PD-L1 surface expression by different tumor stroma cell populations (D; white histograms are fluorescence minus one (FMO) controls) in KP-OVA mice treated or not with Oxa-Cyc ( $\mathrm{n}=2-5$ mice per group). (E) Experimental scheme of micro-computed tomography imaging time points (d122, d146, $\mathrm{d} 193$ ) and ex vivo analysis (d234) of KP-OVA mice treated with Oxa-Cyc and anti-PD-1 + anti-CTLA-4 mAbs either alone or in combination ( $n=5$ mice per group). Tumors were 
induced with a lentiviral vector containing OVA peptide sequences (LucOS). Change in tumor volume (defined by micro-computed tomography at d146 $=\mathrm{T}_{1}$ and $\mathrm{d} 193=\mathrm{T}_{2}$ ) and tumor area in lung tissues (defined by H\&E staining at $\mathrm{d} 234=\mathrm{T}_{3}$ ) in these mice. $(\mathbf{F})$ Coronal micro-computed tomography at $\mathrm{d} 122, \mathrm{~d} 146$ and d193 of an untreated mouse (left) or mouse that received the combination therapy (right). Dotted lines identify tumor nodules that progressed (red) or not (green). (G) Lung tumor burden identification by H\&E staining at $\mathrm{d} 234$ in the same mice. (H) $\mathrm{CD}^{+}$cell (red) infiltration in KP-OVA tumors (tumor contour defined with green dashed-lines, see Figure S5B for comparable images) identified by multiphoton microscopy ex vivo at $\mathrm{d} 234$ in the same mice. Collagen is shown in blue. ${ }^{*} P$ $<0.05 ; * * P<0.01 ; * * * P<0.001 ;$ ns, not significant. See also Figure S5. 

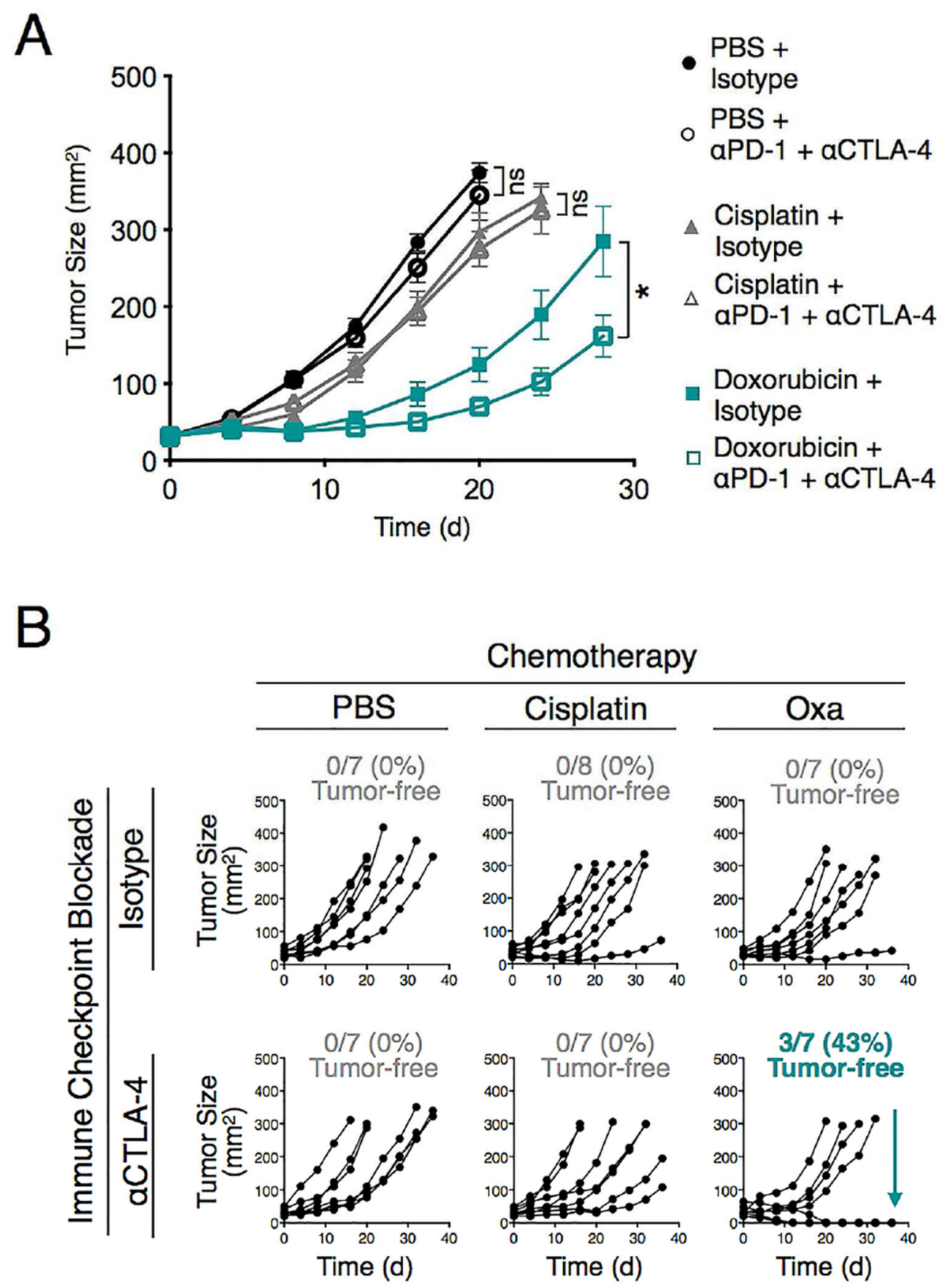

Figure 7. Immunogenic chemotherapeutics improve immune checkpoint blockade treatment against MCA205 fibrosarcoma and CT26 colon carcinoma

A) Tumor size measurement of MCA205 fibrosarcoma-bearing C57BL/6 mice ( $\mathrm{n}=7-8$ per group) treated with PBS or chemotherapy (Cisplatin or Doxorubicin) together with antiPD-1 + anti-CTLA-4 (aPD-1 + aCTLA-4) mAbs or isotype control mAbs. Tumor cells were injected on $\mathrm{d}-8$; the chemotherapeutics were given on $\mathrm{d} 0$ and the mAbs on $\mathrm{d} 8,12$ and 16.. (B) Tumor size measurement of CT26 colon carcinoma-bearing BALB/c mice ( $\mathrm{n}=7-8$ per group) treated with PBS or chemotherapy (Cisplatin or Oxaliplatin (Oxa)) together with 
anti-CTLA-4 or isotype control mAbs. Tumor cells were injected on d-11; the chemotherapeutics were given on $\mathrm{d} 0$ and the $\mathrm{mAbs}$ on $\mathrm{d} 8,12$ and 16. Each line represents an individual mouse. $* P<0.05$; ns, not significant. 